Volume 1, Issue 2

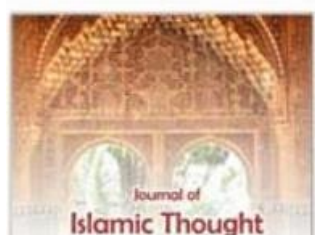
and Civilization ment ine?

tow mis
Journal of Islamic Thought and Civilization (JITC)

Volume 1, Issue 2, Fall 2011

ISSN: 2075-0943, eISSN: 2520-0313

Journal DOI: https://doi.org/10.32350/jitc

Issue DOI: https://doi.org/10.32350/jitc.12

Homepage: https://www.umt.edu.pk/jitc/home.aspx

Journal QR Code:
Article:

Author(s):

Online

Published:

Article DOI:

Article QR

Code:

To cite this article:

Copyright Information
CIVILIZATIONAL CONNECTIONS: EARLY ISLAM AND LATIN-EUROPEAN RENAISSANCE

Dr. S. M. Ghazanfar

Fall 2011

https://doi.org/10.32350/jitc.12.01

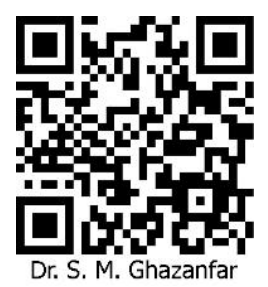

Ghazanfar, S. M. "Civilizational connections: Early Islam and Latin-European renaissance". Journal of Islamic Thought and Civilization 1, no. 2 (2011): 01-34. $\underline{\text { Crossref }}$

This article is open access and is distributed under the terms of Creative Commons Attribution - Share Alike 4.0 International License

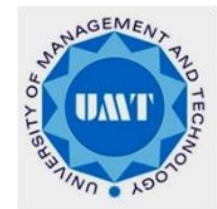

A publication of the

Department of Islamic Thought and Civilization

School of Social Science and Humanities

University of Management and Technology

Lahore
Indexing Partners

INDEX

ISLAMICUS

Crossref

(5) WorldCat

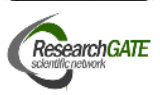

19.2: INTERNATIONAL

INDEX (2) COFERNICU:

GENAM
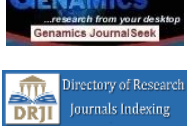

$\mathrm{R} \partial \mathrm{AD} \equiv$
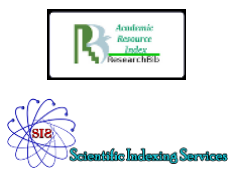


\title{
CIVILIZATIONAL CONNECTIONS: EARLY ISLAM AND LATIN-EUROPEAN RENAISSANCE
}

\author{
Dr. S. M. Ghazanfar
}

\begin{abstract}
The paper discusses four interrelated themes. First, there is a description on the "lost paradigm" of Islamic connections to European Renaissance, followed by a discussion of evidence that this Renaissance depended crucially upon the intellectual armory acquired through prolonged contacts with early Islamic civilization. The influence of many Muslim scholars on Western Enlightenment also cannot be denied. The paper documents the influence of some key Islamic scholars such as Al-Kindi, Ibn-e-Sina, Al-Ghazali and in particular Ibn-e-Rushd, whose writings contributed hugely to the European Enlightenment. This is followed by a discussion of the various sources of transmission of that intellectual armory that enabled Latin-Europeans to exit from the Dark Ages and contributed towards medieval Renaissance as well as subsequent Italian Renaissance.
\end{abstract}

Keywords: Renaissance, Al-Ghazali, Civilization, West, Knowledge, Transmission

"Civilizations no longer exist as separate entities in the way they once did. But modern societies still bear the strong stamp of history, and still identify with each other along cultural fault lines. Among these fault lines, the one that generates the most discussion today runs between Islamic and Western societies" (UN General-Secretary, Kofi Annan, June 28, 1999). ${ }^{1}$

\section{INTRODUCTION}

The above quote is taken from a 1999 speech by the United Nations General Secretary in which he called for a "Dialogue among Civilizations," as a counter to the well-known "clash of civilizations" theme. His reference to the "stamp of history" and "cultural fault lines" provides some context for the present paper. The most significant among those "stamps" and "fault lines" were, of course, the Crusades.

Yet few problems in such discourses are as delicate as that of determining the extent of influence of one civilization upon another. This is especially true with respect to the links between early Islam and Latin-Europe. As Durant puts it, "civilizations are units in a larger whole whose name is history"2; they do not disappear. The past always rolls into the present; indeed, "transplanted ideas, no less than transplanted plants, tend to develop new characteristics in their new environment" ${ }^{3}$.

1 Quoted from a speech, The Dialogue of Civilizations and the Need for a World Ethic, Oxford University Centre for Islamic Studies, June 28, 1999; see UN Press Release SG/SM/7049, June 28, 1999. On November 16, 1999, at the initiative of Iranian President Khatemi, the UN General Assembly adopted a resolution, proclaiming 2001 as the UN Year of Dialogue Among Civilizations. Also, for related discussion, see Civilization: The Magazine of the Library of Congress, (June-July 1999), 73-87 (special guest editor: Kofi Annan)

2 Will Durant, The Story of Civilization: The Age of Faith, Vol. 4. (New York: Simon and Schuster, 1950), 343- 44.

3 Philip K. Hitti, The Arabs: A Short History (N.J.: Princeton University Press, 1943), 221. 
Early Islamic civilization absorbed Greek Hellenism, Judaism, Christianity, Indian mathematics, and Chinese alchemy, and thus developed its own intellectual edifice. This is true also for the Western civilization. Indeed, "It was Islam that carried the light of learning through so many centuries, paving the way for European Renaissance." 4

The mainstream literary-history paradigm, however, has tended to present the evolution of social thought as one straight line of events, moving almost entirely across the Western world, effectively denying history to the rest of the world. Thus, one observes a huge "literature gap" in discussions of 'medieval' history. This extends to just about every discipline. ${ }^{5}$ During the "gap" period, several centuries prior to the emergence of Latin Scholasticism during the $12^{\text {th }}-13^{\text {th }}$ centuries, Islamic scholarship not only absorbed, adapted, and enlarged the re-discovered Greek heritage, but also transmitted that heritage ("as though in a 'corked' bottle," as one scholar puts it), along with its own contributions, to Latin Europe.

Thus was provided the stimulus for developing the human intellect further, for conveying a mold for shaping Western scholasticism, for developing empirical sciences and the scientific method, for bringing about the forces of rationalism and humanism that led to the 12th century Medieval Renaissance, the 15th century Italian Renaissance, and indeed, for sowing the seeds of European Reformation. ${ }^{6}$

Having thus set the tone, my purpose here is to discuss four interrelated themes. First, I briefly comment on the "lost paradigm" of Islamic connections to European Renaissance, followed by discussion of evidence that this Renaissance depended crucially upon the intellectual armory acquired through prolonged contacts with early Islamic civilization. Then, I will document the influence of some key Islamic scholastics, particularly Ibn Rushd, whose writings contributed hugely to the European Enlightenment. This will be followed by a discussion of the various sources of transmission of that Islamic intellectual armory that enlightened the European Dark Ages. I will conclude with some additional corroborative remarks concerning the main theme of this conversation as well as some comments as to the future challenges and potential for the Islamic world.

4 Quoted from speech by U.S. President Barack Obama, (Cairo, June 4, 2009)

5 See S. M. Ghazanfar, "Scholastic Economics and Arab Scholars: The 'Great Gap' Thesis Reconsidered” Diogenes: International Review of Humane Sciences 154 (April-June, 1991): 117-40.

6 See Christopher Dawson, "The Origins of the Romantic Tradition, " The Criterion, 11 (1932):222-248; Christopher Dawson, The Making of Europe: An Introduction to the History of European Unity (New York: Sheed and Ward, 1952); Christopher Dawson, Christopher. The Formation of Christianity (New York: Sheed and Ward, 1967); Etiene Gilson, Reason and Revelation in the Middle Ages (New York: Charles Scribner's Sons, 1948); Charles H. Haskins, The Renaissance of the Twelfth Century (Cambridge, Mass: Harvard University Press, 1927); Charles H. Haskins, Studies in the History of Medieval Science (Cambridge, Mass.: Harvard University Press, 1924); Charles H. Haskins, "Science at the Court of Emperor Frederick II." American History Review 27.4 (July, 1922): 669-694; Charles H. Haskins, "Arab Science in the Western World." ISIS, 17(1925): 478-85; George Makdisi, "The Scholastic Method in Medieval Education: An Inquiry into its Origins in Law and Theology," Speculum: A Journal of Medieval Studies 49 (1974):640661; George Makdisi, "Interaction between Islam and the West." Revue des studes Islamique. 44 (1976):287-309; George Sarton, Introduction to the History of Science; 5 Volumes. (Baltimore, Maryland: Williams and Wilkins, 192748); George Sarton, A Guide to the History of Science (Waltham, Mass.; Chronica Botanica Company, 1952); George Sarton, The Incubation of Western Culture in the Middle East, Library of Congress Lecture (March 1950). (Washington, D.C.: U.S. Government Printing Office, 1951); R. W. Southern, Western Views of Islam in the Middle Ages. (Cambridge, Mass.: Harvard University Press, 1963). 


\section{LITERARY HISTORY: PARADIGM LOST?}

Some years ago, a professional colleague published a paper, entitled, "Paradigms Lost: Western Civilization and the Orient Unexpressed." Lamenting the "false" history encountered in her earlier intellectual life, she noted that she later discovered that her "paradigm had been created by Western Europeans, writing history teleologically as a progression leading only to themselves."7

There are several Western scholars who made such discoveries much earlier, yet the mainstream literary history is not quite accommodative. One such scholar was Harvard's Charles Homer Haskins, who, on the very first page of his magnum opus, The Renaissance of the Twelfth Century (1927), anticipates criticism by those for whom the 15th century Italian Renaissance is more significant. He argues that the "Middle Ages were less dark and less static and the (Italian) Renaissance less bright and less sudden than was supposed." ${ }^{8}$ Then he insists that such a view ignores "the influx of new learning of the East, the shifting currents in the stream of medieval life and thought" . Further, it was during the 12th century when Europe experienced "the revival of learning in the broadest sense" armed with "new knowledge of the Greeks and Arabs and its effects upon Western science and philosophy, and the new institutions of learning...." ${ }^{10}$. After the reconquest, "Spain's part was to serve as the chief link with the learning of the Mohammadan world..." ${ }^{11}$ But, he says, "The story begins in Syria." ${ }^{12}$ His reference is to the "first age of translations," from Greek to Arabic that began in Syria and then flourished during the 9th century in Baghdad's House of Wisdom (Bait-al-Hikma). He goes on, "To their Greek inheritance, the Arabs added something of their own. The reception of this science in Western Europe marks a turning point in the history of Western intelligence." ${ }^{13}$ Others have talked similarly. Thus, "medieval scholars crossing the Pyrenees found the quintessence of all preceding science distilled by the theorists and practitioners of Islam. Historically, by entering the arena of Islamic civilization they had indeed entered the whole vast vibrant world of antiquity as well". ${ }^{14}$ And, "What Islam had to offer them now was not only a spate of enlightening digests of the whole, long, rich evolution but an intelligent discussion of all its essential features, screened and refined through Islam's own intensive experience. ${ }^{15}$

While this "intensive experience" included Islamic world's own "philosophical battles between reason and revelation (thus originated the voluminous "scholastic" literature), similar battles were later ignited in Latin Europe through the transmission of that experience. Indeed, Western scholasticism was inspired by medieval Islamic scholasticism and takes shape beginning in the

7 Diane P. Thompson, "Paradigm Lost: Western Civilization and the Orient Unexpressed," Northern Virginia Review, no.10 (Fall, 1995): 8.

8 Charles H. Haskins, The Renaissance of the Twelfth Century, vi.

9 Ibid., 4.

${ }^{10}$ Ibid., viii-ix.

${ }^{11}$ Ibid., 11.

${ }^{12}$ Ibid., 281.

13 Ibid., 282.

14 Thomas, Goldstein, Dawn of Modern Science (Boston, Mass.: Houghton Mifflin Company, 1988), 98.

${ }^{15}$ Ibid., 102. 
twelfth century, not by chance in regions in contact with the Islamic world, Arab Andalusia and the Sicily of Frederick II. ${ }^{16}$

Now, while Haskins emphasizes "continuity and change" as the hallmark of the Middle Ages, one typically observes "discontinuity" and almost universalization of the European Dark Ages in literary history in almost all branches of knowledge. Much of the literature, unlike Haskins' works, reflects painstaking efforts to minimize the significance of Islamic linkages; the Greek heritage becomes the primary emphasis. Such omissions in historiography persuade one eminent medievalist to argue that "the Arabic component of our paradigmatic view of the Middle Ages has always remained incidental; it has never been systemic" and the "myth of Westernness" is "too much shaped by cultural prejudices" that are "still quite powerful in the real world of literary historiography."17

Thus, Arab-Islamic scholarship is treated as nothing more than a holding operation .... as a giant storehouse for previously discovered scientific results, keeping them until they could be passed on for use in the West." ${ }^{18}$ Further, we can readily agree on the more recent Western impact on the Islamic world, for we are our own witnesses. However, it becomes somewhat unsettling when we learn of the distant, far more significant impacts in reverse. Occasional references notwithstanding, what is almost endemic concerning Islamic heritage is the tone and style that is "other-oriented," exclusionary, remote, denigrating, or outright offensive. The names of a few medieval Islamic scholars are tolerated, but merely as "librarians," not original thinkers, and then as "transmitters" of the Greeks, as though Greek knowledge was kept in a freezer and then centuries later it was handed over to thaw in Europe-what I call the "freezer model" of transmission. Such posturing is "garbled falsification" and "colossal misrepresentation", ${ }^{19}$ "a travesty of truth" 20 , and "worse than a lie". ${ }^{21}$

Having narrated a bit of a background for this paper, I will now proceed to the main task: that is, to document some evidence as to the influence of a few prominent early Islamic scholars whose writings contributed to European Awakening, followed by a discussion as to the sources of transmission of that knowledge.

${ }^{16}$ Samir Amin, Eurocentricism (translated into English by Russell Moore). (New York, N.Y.: Monthly Review Press, 1989), 56; see also George Makdisi, "The Scholastic Method in Medieval Education: An Inquiry into its Origins in Law and Theology," Speculum: A Journal of Medieval Studies 49 (1974):640-661.

${ }^{17}$ Maria Rosa Menocal, The Arabic Role in Medieval Literary History: A Forgotten Heritage (Philadelphia: University of Pennsylvania Press, 1987), 9, 13-14.

${ }^{18}$ Colin A. Ronan, Science: Its History and Development among the World's Cultures (New York: Facts on File Publishers, Hemlyn Publishing Group Limited, 1982), 203.

${ }^{19}$ Robert Briffault, The Making of Humanity (London: George Allen \& Unwin Ltd.; and New York: The Macmillian Company, 1919), 189, 201.

${ }^{20}$ Colin A. Ronan, Science: Its History and Development among the World's Cultures, 203.

${ }^{21}$ George Sarton, A Guide to the History of Science, 27; see also Amin, Daniel, Dawson, Crombie, Southern, and others) 


\section{ISLAM-LATIN EUROPE LINKS: NATURE AND IMPACT $\underline{22}$}

Briefly now, what was the nature and impact of these influences? According to Goldstein, The effect was an intellectual stimulation without parallel. Virtually every aspect of European life from religion and philosophy to governmental institutions to architecture, personal mores, and romantic poetry, was profoundly affected ... and the fascination of the enemy culture that had ruled over the Iberian Peninsula had spread secretly and slowly since the 10th century. By the twelfth it attained the proportion of a cult. ${ }^{23}$ Further, under the impact of this encounter, the West took the step toward the cultivation of specialized sciences, out of the original philosophical core. "Every single specialized science in the West owes its origin to the Islamic impulse, or at least its direction from that time on. It was from Islam that the Middle Ages learned to look on nature as an infinitely varied reality, not as a philosophical idea. ${ }^{24}$ Haskins enumerates several disciplines in which Arab-Islamic knowledge flowed to the West: mathematics, astronomy, physics, chemistry, geography, astrology, medicine, veterinary medicine, zoology, botany, and, of course, philosophy and science, including the scientific empiricism. ${ }^{25}$ Indeed, Haskins' "vision of a profoundly secular renaissance," with its emphasis on reason in human affairs and rationalism in understanding nature evolved through the influence of Arab-Islamic civilization whose own renaissance, including the 'secular-sacred' mix of the young Islamic faith, was stimulated by the Greeks. ${ }^{26}$ Aside from other influences, the Crusades induced various influences, but, more importantly, they also saw the development of a new secular ideal of chivalry which seems the direct antithesis of St. Bernard's ideal of Christian Knighthood ... and at the same it was equally remote from the barbaric heroism of Northern feudalism. ${ }^{27}$ Then this medievalist adds emphatically and says that new secular ideal "has no roots in the earlier medieval culture of the West. It is neither Christian, nor Latin, nor Germanic. It appears abruptly in Southern France about the time of the First Crusade without any preparation or previous development.... the origins of the new style [i.e., the secular ideal] are to

${ }^{22}$ It is tempting to append here a partial list of several key Islamic "impactors" and Latin-European "impactees" Some "impactors" Al-Kindi, d.873; Al-Razi, d.925; Al-Farabi, 950; Al-Khwarizmi, d.976; Ibn-Sina (Avicenna), d.1036; Ibn-Haitham, d.1039; Al-Biruni, d.1048; Al-Ghazali, d.1111; Ibn-Tufail, d.1186, Ibn-Rushd (Averroes), d.1198; Ibn-al-Arabi, d.1240; Ibn-Khaldun, d.1406; etc.

---Some "impactees" -- Robert Grossetteste, Alexander of Hales, Albertus Magnus, Raymund Lull, St. Thomas Aquinas, Domingo Gundisalvo, Duns Scotus, Siger of Brabant, Nicholas Oresme, Gerbert of Aurillac (later Pope Sylvester II, 999-1003), Abelard of Bath, Roger Bacon, Peter Adelard, John Peckham, Henry of Gant, William of Occam, Dante Aligheri, Rene Descartes, Nicholas Copernicus, Gailileo Galilei; etc.

23 Thomas Goldstein, Dawn of Modern Science (Boston, Mass.: Houghton, Mifflin Company, 1988), 94; See also for pre$12^{\text {th }}$ century connection Josiah C. Russell, Twelfth Century Studies (New York: AMS Press, 1978); Mary C. Welborn, "Lotharingia as a Center of Arabic Scientific Influence in the Eleventh Century" ISIS. 16 (1931):188-99; Diane P. Thompson, "Paradigm Lost: Western Civilization and the Orient Unexpressed," Northern Virginia Review, no.10 (Fall, 1995): 5-8; James W. Thompson, "The Introduction of Arabian Science into Lorraine in the Tenth Century," ISIS. $38: 12$ (May, 1929.) 184-193

24 Thomas Goldstein, Dawn of Modern Science, 99.

25 see Eugene A. Myers, Arabic Thought and the Western World (New York: Frederick Ungar Publishing Company, 1964); Mehdi Nakosteen, History of Islamic Origins of Western Education A.D. 800-1350, (Boulder, Col.: University of Colorado Press, 1964); D. M. Dunlop, Arab Civilization to A.D. 1500 (New York: Praeger Publishers, 1971) and others.

${ }^{26}$ Robert Benson, Robert and Giles Constable (Editors). Renaissance and Renewal in the Twelfth Century (Proceedings: 1977 Conference in commemoration of Charles H. Haskins' contributions). (Cambridge, Mass.: Harvard University Press, 1982), xxiii.

${ }^{27}$ Christopher Dawson, The Making of Europe: An Introduction to the History of European Unity (New York:Sheed and Ward, 1952), 152. 
be found in the rich and brilliant society of Muslim Spain. ${ }^{28}$ And such contacts generated "that confidence in the power of reason and that faith in the rationality of the universe without which science would have been impossible." ${ }^{29}$ Indeed, for factors such as suggested here, Southern calls the 12th century "The Century of Faith and Reason," the title of his chapter 2, preceded by a chapter on "the Age of Ignorance. ${ }^{\text {"30 }}$

Similar impact from contacts with the East is suggested by Ferruolo. He argues that the fact that "Western Europe experienced a renaissance in the twelfth century comparable to the Renaissance that began in Italy is an old and well-established idea among the medievalists." ${ }^{31}$ However, Ferruolo suggests two key developments that distinguish the earlier renaissance from the other:

(i) the rise of humanism - human dignity, rationalism and reason, nature as comprehensible ("earlier, humanity was viewed as frail"); and (2) the discovery of the individual-"one of the most important developments in the years between 1050 and 1200," meaning self-discovery, individual expression, interest in human relations, and "a system of ethics judged by standards of inner intention rather than external action." ${ }^{32}$ And how did these revolutionary and novel developments emerge? Ferruolo provides some clues as to their Arab-Islamic links. The Crusades were of central importance ... they helped to shape European attitudes, feelings, and values ... For more than two centuries, Western Europeans were preoccupied with the Greeks and the Saracens. The cultural advances they made during this time were undoubtedly influenced by the rediscovery of the classical past, but the greater stimulus probably came from the discovery of the Byzantium and Islam, two very different and hostile cultures that share the same past. ${ }^{33}$

While the preceding paragraphs provide a general picture of the cultural transformation and reorientation of Latin-Europe through contacts with the Islamic civilization, there is a plethora of publications that documents the specific, disciplinary contributions of Islamic scholars and their influence upon the European scholars (perhaps the most prominent name among the later being the Prince of Scholasticism, St. Thomas Aquinas [1225-1274] who studied at the University of Naples, established by Frederick II in 1224 for the specific purpose of promoting and absorbing Arab-Islamic knowledge). Consistent with the literature gap tradition, however, the pursuits of our ordinary scholar hardly ever encounter, or exposed to, such prolonged cross-cultural, civilizational links. On the other hand, there is hardly any work on early medieval literary history that does not provide some clues or evidence for the astute scholar as to the overwhelming multi-dimensional

${ }^{28}$ Christopher Dawson, The Making of Europe: An Introduction to the History of European Unity, 153; also see Etienne Gilson, Reason and Revelation in the Middle Ages (New York: Charles Scribner's Sons, 1948); Rose Wilder Lane, The Discovery of Freedom: Man's Struggle against Authority (New York: John Wiley and Sons, 1970); George Sarton, The Incubation of Western Culture in the Middle East. Library of Congree Lecture (March 1950) (Washington: D.C.:US Government Printing Office, 1951); Henry G. Weaver, The Mainspring of Human Progress (New York: The Foundation for Economic Education, Inc., 1953); and others

${ }^{29}$ Christopher Dawson, "The Origins of the Romantic Tradition," The Criterion, 11 (1932):230.

${ }^{30}$ R. W. Southern, The Making of the Middle Ages (New Haven, Conn.: Yale University Press, 1959); also see Toby E. Huff, The Rise of Early Modern Science: Islam, China, and the West (New York: Cambridge University Press, 1993), Huff, especially his chapter 3, "Reason and Rationality in Islam and the West;" and Packard's chapter 3, "The World of the Mind in the Twelfth Century)

${ }^{31}$ preceding even Haskins' book, 12th Century Renaissance.

32 Stephen C. Ferrueolo, "The Twelfth Century Renaissance," in Renaissances Before the Renaissance: Cultural Revival of Late Antiquity and the Middle Ages, Edited by WarrenTreadgold. (Stanford, Calif.: Stanford University Press, 1984), 123-128.

${ }^{33}$ Ibid., 137. 
medieval encounters with the Islamic civilization that lurk vividly in the background, however minimally, disparagingly or distantly noted. An example of such literature is the 1878 book by Paul Lacroix, in which the author eloquently discusses the evolution of various specialized disciplines in Europe, and in each case, there are scores of references, though noted hesitatingly and in less than flattering terms, linking European scholars to their "pagan" Arab predecessors. And there are other similar works where Arab-Islamic influences loom large, and to the extent noted; done so as secondary and distant. ${ }^{34}$ As Norman Daniel points out, we nowhere find admission that there was an alien source for the new ideas of Western Europe in the 12th century in the lay world ${ }^{35}$ for there tends to be "a cultural filter in acquiring knowledge from an alien source considered to be tainted." ${ }^{136}$ Further, "Islam was at one and the same time the great enemy and the great source of higher material and intellectual culture." ${ }^{37}$

One of the most significant and comprehensive sources in this context is the scholarship of George Sarton, about the most prolific historian of the "history of knowledge" and a contemporary of Haskins at Harvard. His 5-volume, encyclopedic, Introduction to the History of Science (1927-48) is a treasure, as well as his A Guide to the History of Science (1952). However, there are numerous other publications which document the Islamic-Latin Europe connections. ${ }^{38}$ Some of these references provide extensive bibliographies of their own-e.g., Chejne, Daniel, Menocal, Myers, Qadir, Southern, etc. Indeed, there are some very recent books, with interesting titles e.g., The House of Wisdom; What Islam Did for Us; Lost History, etc.written by Western scholars Lyons, Morgan, Wallace-Murphy, and others.

\section{SOME KEY ISLAMIC SCHOLASTICS AND THEIR IMPACT}

Presently our task is to briefly explore the intellectual sources of medieval Islamic-European connections that gave rise to what Haskins called the "vision of a profoundly secular renaissance." That vision was inspired through the scholarship of medieval Islamic "giants" (as Sarton referred to them), such as Al-Kindi (801-873), Al-Razi (865-925), Al-Farabi (870-950), Ibn Sina (9801037), Al-Ghazali (1058-1111), and, in particular, Ibn Rushd (1126-1198). Europe of the late Dark Ages was receptive, but such a vision, as noted before, "had no roots in the earlier medieval culture of the West. It is neither Christian, nor Latin, nor German. It appears abruptly in Southern France about the time of the First Crusade, without any preparation and previous development

${ }^{34}$ see Robert Benson and Giles Constable (Editors). Renaissance and Renewal in the Twelfth Century Claggett, et al.; Jean Gimpel, The Medieval Machine: The Industrial Revolution of the Middle Ages, (New York: Holt, Rinehart and Winston, 1976); Jean Gimpel, The Medieval Machine: The Industrial Revolution of the Middle Ages (New York: Holt, Rinehart and Winston, 1976); John E. Murdoch, and Edith D. Sylla (Editors). The Cultural Context of Medieval Learning (1973 Conference Proceedings). (Boston, Mass.: D. Reidel Publishing Company, 1975); Sidney R. Packard, 12th Century Europe: An Interpretative Essay (Amherst, Mass.: University of Massachusetts Press, 1977); Tina Stiefel, The Intellectual Revolution in Twelfth Century (New York: St. Martin's Press, 1985); Warren Treagold, (Editor). Renaissances before the Renaissance: Cultural Revival of Late Antiquity and the Middle Ages. (Stanford, Calif.: Stanford University Press, 1984); and others

${ }_{35}$ Norman Daniel, The Arabs and the Medieval West (London: Longman Group, 1975-I), 105-106.

${ }^{36}$ Norman Daniel, The Cultural Barrier: Problem in the Exchange of Ideas (Edinburgh, England: Edinburgh University Press, 1975-II.), 87.

${ }^{37}$ W. Montgomery Watt, Islamic Surveys: The Influence of Islam on Medieval Europe (Edinburgh, England: Edinburgh University Press, 1972), 172.

38 (see the extensive bibliography) 
...The origins of the new style are to be found in the rich and brilliant society of Muslim Spain." ${ }^{39}$ Thus emerged, the "confidence in the power of reason and that faith in rationality of the universe without which science will have been impossible." ${ }^{40}$

The primacy of reason in pursuing human affairs was indeed the singularly unique and revolutionary attribute that the Islamic legacy bestowed upon medieval Europe. And reason emerged as a force to counter the authority of the Church, for the popes "judged all and could be judged by none." ${ }^{41}$ It was this social environment and contacts with the Islamic civilization that persuaded twelfth century English heretic, Adelard of Bath, "trained (as he says) by Arab scientists," to assert, while addressing his nephew, "For I was taught by my Arab masters to be led only by reason, whereas you were taught to follow the halter of the captured image of authority." 42

While Ibn Rushd's role in this "rational" evolution is acknowledged to be the most pronounced, there were others who not only influenced Ibn Rushd but also directly impacted subsequent LatinEuropean discourses. The task of introducing Greek philosophy into Islam and of underscoring its essential conformity with the Islamic worldview fell, first, to Abu Yusuf Al-Kindi. But there were also others.

\section{(1) AL-KINDI (801-873 AD)}

The founder of the Islamic Peripatetic School of philosophy and the author of 270 treaties ranging from logic and mathematics to physics and music, Abu Yusuf al-Kindi, in recognition of his tireless efforts to make philosophy acceptable to theologians, is known as the "philosopher of the Arabs." He is also the only great Muslim philosopher of antiquity. A thorough Mu'tazlite, he wrote that truth is universal and supreme, and that philosophy is but another form of the message which the prophets have carried.

Despite his philhellenic sympathies, Al-Kindi remained thoroughly committed to his Islamic heritage, as interpreted chiefly by the rationalist theologians of the 8th and 9th centuries, the Mu'tazilah. He was virtually alone in attempting to give philosophical support to the basic Islamic scriptural concepts. Al-Kindi's two treatises on geometrical and physiological optics were utilized by Roger Bacon (1214-1292), who was also influenced later by the works of Al-Haitham (d. 1039). His influence was so widely felt that the Italian physician-mathematician, Geromino Cardano (1501-1576) considered him "one of the twelve giant minds of history."

\section{(2) AL-RAZI (865-925 AD)}

Known as the greatest physician of Islam, Muhammad Abu Bakr Zakariya Al-Razi earned the title of "Arabic Galen" and "most brilliant genius of the Middle Ages" for achievements in medicine, but also called the founder of philosophy of nature in Islam. He was a free thinker and an important philosophical figure who was even more radical than Al-Kindi in his attachment to Greek rationalism.

${ }^{39}$ Christopher Dawson, The Making of the Europe: An Introduction to the History of European Unity, 153.

${ }^{40}$ Christopher Dawson, The Formation of Christianity (New York: Sheed and Ward, 1967), 230.

${ }^{41}$ Will Durant, The Story of Civilization: The Age of Faith, Vol. 4, 954; Joseph R. Strayer, On the Medieval Origins of the Moderrn State (Princeton., N. J.: Princeton University Press, 1970), 8.

${ }^{42}$ Tina Stiefel, The Intellectual Revolution in Twelfth Century, 71, 80.

${ }_{43}$ Eugene A. Myers, Arabic Thought and the Western World, 11. 
Constantine the African translated into Latin two of Al-Razi's philosophical works and Gerard of Cremona translated his medical work, Tib al-Mansouri, under the title of Liber Almansorius. AlRazi's greatest work, Kitab al-Hawi (Liber de Continens) was translated into Latin and was published several times.

\section{(3) AL-FARABI (870-950 AD)}

Muhammad Abu-Nasr Al-Farabi wrote extensively in different fields. He wrote the Introduction to Logic and Abridgement of Logic; his interest in natural science led to his commentaries on Aristotle's Physics and on the movement of the celestial bodies. He also wrote The Power of the Soul, The Unity and the One. The Intelligence and the Intelligible, and a commentary on Alexander of Aphrodisias' De Animis. His The Model City continues to be of sociological interest even today. However, Al-Farabi is best known for The Encyclopedia, a definitive account of all branches of sciences and art, and The Political Regime, also known as The Book of Principles.

The influence of Al-Farabi upon two of 13th century's most prominent Latin scholastics, Albertus Magnus and his student, St. Thomas Aquinas, is profound. Hammond documents the similarities by placing Al-Farabi's arguments "side by side with those of St. Thomas in order to aid the reader in comparing them." ${ }^{44}$ Thus, "we see without doubt the influence of the former [Al-Farabi] on the latter [St. Thomas] but not vice versa." ${ }^{45}$ Further, "Albertus Magnus and St. Thomas and others borrowed from him a great amount of material hitherto regarded by many as a product of their speculation, while in reality it is not." ${ }^{46}$

\section{(4) IBN SINA (980-1037 AD)}

Abu Ali Al-Husain Ibn Sina was another precocious genius of medieval Islam whose work spanned vast areas of knowledge. His magnum opus, The Canon of Medicine (al-Qunan fil-Tibb), remained the standard text - about like Gray's Anatomy - until the birth of modern medicine. He has been credited with at least 99 books on various topics. His Kitab al-Shifa (The Book of Healing) covered practical knowledge on civic affairs and theoretical knowledge on physics, mathematics, and metaphysics.

Having mastered the metaphysics of Aristotle, Ibn Sina's writings not only formed a bridge between the Greeks and Renaissance Europe, but also constituted a distinctive school known as Latin Avicennism in medieval Europe, led by William of Auvergne. Less well known than the school of Latin Averroism, it was an attempt to reconcile the ideas of St. Augustine with Aristoteleniasm.

Ibn Sina's influence reached out to make its mark on two great minds-Ibn Rushd and the eminent Jewish scholastic, Maimonides (1135-1204) and into Christendom to the various Latin-Scholastics (Albertus Magnus, St. Thomas Aquinas, Duns Scotus, John of Seville, and others). Roger Bacon called him "the chief authority in philosophy after Aristotle," and Aquinas spoke with as much respect of him as of Plato. "47 Avicenna and Averroes were lights from the East for the Schoolmen, who cited them next to the Greeks in authority." 48

${ }^{44}$ R. Hammond, The Philosophy of Alfarabi and its Influence on Medieval Thought (New York: Hobson Press, 1947), 65.

${ }^{45}$ Ibid., 29.

46 Ibid., ix; also see Sarton.

${ }^{47}$ Myers, Arabic Thought and the Western World, 34.

48 Will Durant, The Story of Civilization: The Age of Faith, Vol. 4, 342. 


\section{(5) ABU HAMID AL-GHAZALI (1058-1111 AD)}

The most prominent of the early Islamic theologian-scholastics is Abu Hamid Al-Ghazali, "acclaimed as the greatest ... certainly one of the greatest" (Watt, 1963, vii). He exerted great influence upon Jewish and Christian scholasticism and succeeded in reconciling his pragmatic tendencies with strict Moslem orthodoxy" (Myers, 35). The most significant of his writings is the 4-volume Ihya Ulum al Din (The Revival of the Religious Sciences), which 'parallels' St. Thomas Aquinas' Summa Theologica. ${ }^{49}$ Incidentally, Al-Ghazali's works, including the Ihya, were translated into Latin before 1150 AD. ${ }^{50}$

Al-Ghazali's scholarship assumes its greatest significance in relation to the larger philosophicaltheological controversies of the time. He challenged other Islamic scholastics, whose Aristotelian rationalism threatened Islam itself. His attempt at reconciliation appeared in his Tahafat alFalasifah (The Incoherence of Philosophers), which was later challenged by Ibn Rushd, as we shall see.

As the works of Islamic rationalists, chiefly Ibn Rushd, reached medieval Europe, similar challenges were perceived even to Christianity, and there were fears of the "liquidation of Christian theology." ${ }^{51}$ Thus, relying heavily on Al-Ghazali's synthesis, "St. Thomas was led to write his Summas to overcome that threat." ${ }^{52}$ And, "since Ghazali placed science, philosophy and reason in position inferior to religion and theology, the Scholastics accepted his views, which became characteristic of most medieval philosophy." ${ }^{53}$ Thus, "Europe as well as the Muslim East felt the impact of Al-Ghazali's teaching. Echoes of his voice are heard in the reflections of Blaise Pascal, and his work was paralleled by Thomas Aquinas in the discourse on Christian doctrine and in other portions of Summa Theologica." ${ }^{54}$ His "teaching is quoted by St. Thomas and other scholastic writers" ${ }^{45}$; and it is generally known that St. Thomas' synthesis "was deeply influenced by Muslim philosophers, chiefly al-Ghazali." ${ }^{56}$

Further, the Spanish Dominican monk, Raymond Martin directly benefited from Al-Ghazali's texts in his books, entitled, Pigio Fidei and Explanation Symboli; and "the arguments have been taken exactly as they were in the originals." ${ }^{57}$ St. Thomas used some texts of Al-Ghazali's in Contra Gentiles, either directly or through the mediation of Raymund Martin. St. Thomas, who had received his education from the Dominican order in the University of Naples, had known alGhazali's philosophy well, and used his arguments in attacks on Ibn Rushd and his Aristotelian commentaries. This university was established in 1224 by Frederick II, chiefly to assimilate Islamic philosophy and science.

49 Ibid., 950.

${ }^{50}$ Myers, Arabic Thought and the Western World, 39.

51 Will Durant, The Story of Civilization: The Age of Faith, Vol. 4, 954.

${ }_{53}^{52}$ Ibid.

${ }^{53}$ Myers, Arabic Thought and the Western World, 39-40.

54 Jurji, Collier's Encyclopedia, 1979, 13:312-13.

55 De Lacy O'Leary, Arabic Thought and its Place in History (New York: Kegan Paul, Tench, Trubner \& Co., Ltd., 1922), 208.

${ }^{56}$ See also F.C. Copelston, A History of Medieval Philosophy (New York: Harper \& Row, Publishers, 1972), 181; Myers, Arabic Thought and the Western World, 42; Nicholas Rescher, Studies in Arabic Philosophy (Pittsburgh, Penn.: University of Pittsburgh Press, 1966), 156.

${ }^{57}$ M. M. Sharif, (Editor), A History of Muslim Philosophy, 2 Volumes, (Weisbaden, Germany: Otto Harrassowitz, 1966), 1361. 
Incidentally, Al-Ghazali's Ihya included discourses on the discipline of economics, remarkably similar to those found in the writings of later European scholars, including Adam Smith. ${ }^{58}$ It is encouraging to note that economic thought originating from Al-Ghazali and others is now incorporated in some American textbooks on the subject.

\section{(6) IBN RUSHD (1126-1198 AD)}

We now turn to the most influential intellectual of Cordoba, Ibn Rushd. The "heresies" of iconoclasts, such as Abul Walid Mohammad Ibn Rushd, generated unprecedented intellectual upheaval which forever transformed Western social thought, especially in medieval LatinChristendom. Ibn Rushd (latinized 'Averroes') was the ultimate rationalist, the Aristotelian heretic of early Islam and Christianity. His singular influence in stimulating Western Renaissance is acknowledged "as the landmark in the history of Western civilization." ${ }^{59}$ Along with Ibn Sina, he is "the greatest name in Arabian [Islamic] philosophy ... whose influence spread, in many directions, through the duration of the middle ages, then in the epoch of the Renaissance up to the very threshold of modern times." ${ }^{60}$ Indeed, "he was the greatest Muslim philosophers of the West, and one of the greatest of medieval times." ${ }^{61}$ Roger Bacon ranked Ibn Rushd next to Aristotle and Ibn Sina. ${ }^{62}$

Trained as a lawyer and a physician, Ibn Rushd's role as advisor to the Caliph initiated him into philosophy. He wrote extensive commentaries on Aristotle, and others. He also wrote a 7volume medical encyclopedia, Kitab al-Kulliyat fil-Tibb (hence the Latin name Colliget, a corruption of the word "kulliyat," meaning "generalities"), used at European universities until the 18th century. Though his scholarship in medicine has been eclipsed by his fame as a philosopher, he was "one of the greatest physicians of the time." 63

Ibn Rushd's philosophy was in the tradition of prevailing Islamic scholasticism, attempting to reconcile Islamic faith with reason in light of the available Greek heritage. His Commentaries on Aristotle were translated into Latin and Hebrew. There soon appeared super-commentaries on his commentaries - which itself is a testimony to his influence. The works of Aristotle and Ibn Rushd

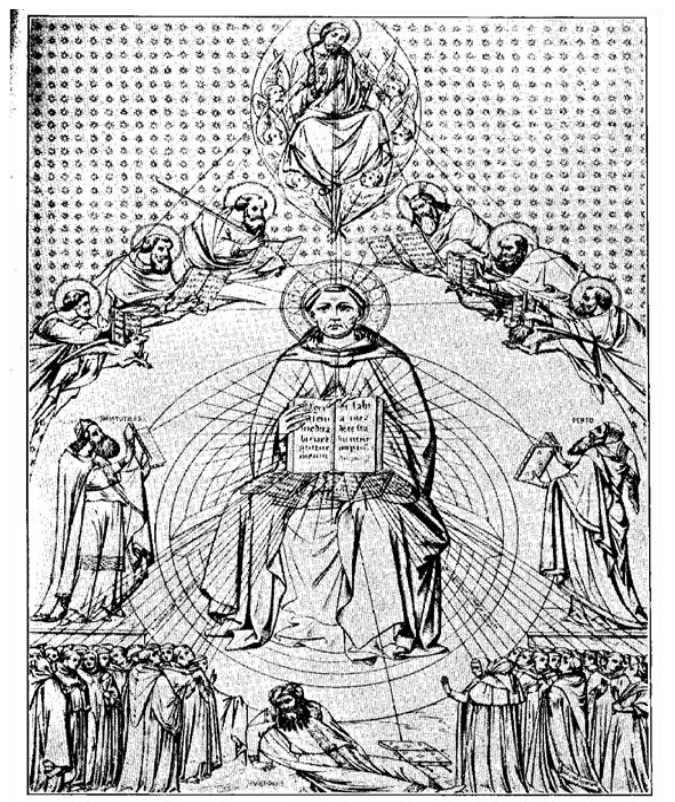

ST. THOMAS AQUINAS OVERCOMING AVERROES

${ }^{58}$ S.M. Ghazanfar, and A. Azim Islahi. "Explorations in Medieval Arab-Islamic Economic Thought: Some Aspects of Ibn Qayyim's Economics (691-751AH/1292-1350AD)," History of Economic Ideas (Italy) 1997. 5:1:7-25

59 Etienne Gilson, 1938, 30.

${ }^{60}$ Etienne Gilson, History of Christian Philosophy in the Middke Ages (New York: Charles Scribner's sons, 1955), 217.

${ }^{61}$ Sarton, II-1, 356.

62 Will Durant, The Story of Civilization: The Age of Faith, Vol. 4, 338.

${ }^{63}$ Sarton, II-1, 305. 
in their Latin translations were used not only in the curriculum at Naples (where St. Thomas studied), but were also sent to the Universities of Paris and Bologna. Nowhere did Averroism strike deeper roots than in the Universities of Bologna and Padua, the latter became the "hot-bed" of Averroism. ${ }^{64}$

Like others before him, Ibn Rushd was criticized for suggesting that revelation must be guided by reason. In his view, the noblest form of worship was to study God through His works, using the faculty of the mind. For his rebuttal (Tahafut al-Tahafut, or Incoherence of the Incoherence) of Al-Ghazali's arguments, Ibn Rushd is rather well known. His dispute with Al-Ghazali provides a fascinating view of the issues which engaged the minds of early Muslim scholars. In Al-Ghazali's scheme, everything is the result of continuous divine intervention and the divine will; any causal link is secondary. But, for Ibn Rushd, while divine will may be the ultimate cause, "To deny the existence of efficient causes which are observed in sensible things is sophistry...Denial of cause implies the denial of knowledge and denial of knowledge implies that nothing in the world can really be known" (Tahafut al-Tahafut. ${ }^{65}$

Once the rediscovery of Aristotle through Ibn Rushd's writings was complete, the philosophers and theologians alike found themselves in possession of the greatest intellectual reservoir ever developed up to that time. Ibn Rushd was "the Great Commentator." Influenced by his writings, philosophers and theologians split into two major groups: the "liberal," pro-Averroists, known as the Latin Averroists, with Siger of Brabant (1240-1280) at their head, generally identified with the Franciscan Friars (Peter Abelaard, 1079-1142; Adelaard of Bath, 1080-1152; Roger Bacon, 12141294; Duns Scottus, 1265-1308; and others); and the "conservative," anti-Averroists, Dominican Monks, led by St. Thomas Aquinas (along with Albertus Magnus, 1206-1274; Raymond Martin, d.1284; Raymund Lull, 1232-1315; and others). The issues were legion-metaphysical, philosophical, and practical. It may be noted, however, that even Ibn Rushd's critics, including St. Thomas, did not escape his influence, and their understanding of Aristotle was conditioned by Ibn Rushd's' interpretations. In 1852, Ernest Renan expressed this paradox very well, "St. Thomas is the most serious adversary that the Averroes doctrine has encountered, and yet one can go further to say, paradoxically, that he is the greatest disciple of the Great Commentator. Albert the Great owes everything to Avicenna; St. Thomas, as philosopher, but above all to Averroes."

Etienne Gilson in his Reason and Revelation in the Middle Ages accords Ibn Rushd the distinction of having established the "primacy of reason;" and for this, he regards Ibn Rushd as the "herald of rationalism" long before the Renaissance ${ }^{67}$. Rationalism was "born in Spain, in the mind of an Arabian philosopher, as a conscious reaction against the theologism of the Arabian divines." 68 Gilson adds that Ibn Rushd "bequeathed to his successors the ideal of a purely rational philosophy, an ideal whose influence was to be such that, by it, even the evolution of Christian philosophy was

\footnotetext{
${ }^{64}$ M. M. Sharif, (Editor). A History of Muslim Philosophy, 2 Volumes, 1381.

${ }^{65}$ [translated by S. Van Dern Bergh; London, E.J. Gibb Memorial Series, Vol.1], 317, quoted in Pervez Hoodbhoy, Islam and Science: Religious Orthodoxy and the Battle for Rationality (London and New Jersey: Zed Books, 1991), 114.

${ }^{66}$ Majid Fakhri, Averroes, Aquinas, and the rediscovery of Aristotle in Western Europe (Washington, D. C.: George town University, 1997), 5.

${ }^{67}$ Ibid., 34

${ }^{68}$ Mjaid Fakhri, Averroes, Aquinas, and the rediscovery of Aristotle in Western Europe, 6; Etienne Gilson, Reason and Revealtion in the Middle Ages, 37.
} 
to be deeply modified." 69 What became pivotal to St. Thomas' own philosophy, Gilson attributes to Ibn Rushd the recognition "that nothing should enter the texture of metaphysical knowledge save only rational and necessary demonstrations." ${ }^{, 70}$ However, unlike some of his adversarial Latin Averroists, St. Thomas was not willing to concede that either Aristotle or Ibn Rushd were infallible.

Despite the enthusiasm for Ibn Rushd's Aristotelian Commentaries in Paris during the thirteenth century, serious questions arose as to the compatibility of Ibn Rushd's Aristotelianism with the Christian doctrine. And there were condemnations en mass-medieval "Mcarythism" ("Islamophobia?") and even a 13th century Papal Inquisition against the Christian-Averroistic "heretics". The targets were mainly Latin Averroists, led by Siger of Brabant, who were suspected of subscribing to the "double-truth" doctrine: some truths philosophical, others theological; and reason was superior to faith. St. Thomas in his On the Unity of the Intellect against the Averroists confirms this suspicion but denies the doctrine. Ibn Rushd himself did not subscribe to such a thesis; and according to Gilson and other medievalists, it is doubtful that even Siger himself did so. This doctrine, however, was a godsend for the scientifically-minded scholars in the West, who were condemned and persecuted by the Church and the State. For this reason, de Wulf calls Ibn Rushd the "doctor of anti-Scholastics.",

For Ibn Rushd, the primacy of reason is unquestioned but compatible with faith. In his Harmony of Philosophy and Religion (Fasl al-M'aqal), which was not available in Latin to St. Thomas, Siger of Brabant or their contemporaries, Ibn Rushd maintains a position which may be called the "parity" or "harmony" of truth, philosophical and theological. Thus, philosophical truth, although superior to religious truth, is not really incompatible with, or even different, from it. The only difference is the path to truth-philosophical and the theological. For any apparent conflict between the religious texts and the philosophical texts, it is the philosophers' duty to resolve the conflict by recourse to the method of interpretation, according to Ibn Rushd; after all, he would say, it is "they who are confirmed in knowledge."72 Thus, in response to Al-Ghazali's charge of infidelity (kufr), Ibn Rushd argues that, if the inner meaning of the Qur'anic passages is understood, the position of the philosophers accords with that of the theologians. ${ }^{73}$

However, Ibn Rushd's Aristotelian commentaries and his own contributions rapidly became the ruling mode of social thought in the West. Scholars of medieval Europe were provoked and inspired by Ibn Rushd's writings. Whereas some Muslim scholars and their Latin successors tried to "Islamize" and "Christianize" Hellenism, Ibn Rushd's commentaries and rationalism seemed to excessively "hellenize" Islam and Christianity-or so he was accused. Thus, his Muslim contemporaries persecuted him and the Muslim posterity almost ignored him and allowed his works to be lost. Jews preserved many of them. In Latin Christianity, the commentaries were translated into Latin from the Hebrew, fed the heresies of Siger of Brabant and the rationalism of the Italian school of Padua, and threatened the foundations of Christianity. Relying on the more compatible Al-Ghazali, St. Thomas recognized that some dogmas of religion were beyond reason

\footnotetext{
${ }^{69}$ Etienne Gilson, Reason and Revealtion in the Middle Ages, 38.

${ }^{70}$ Majid Fakhri, Averroes, Aquinas, and the rediscovery of Aristotle in Western Europe, 6; Etienne Gilson, Reason and Revealtion in the Middle Ages, 79.

${ }^{71}$ M. M. Sharif, A History of Muslim Philosophy, 2 Volumes, 1380.

${ }_{72}^{72}$ Qur'an, Sura 3:5-6.

${ }^{73}$ Majid Fakhri, Averroes, Aquinas, and the rediscovery of Aristotle in Western Europe, 33-34.
} 
and must be accepted by faith alone. "The aim of his life was to reconcile Aristotelianism and Muslim knowledge with Christian theology"74; and "Thomas Aquinas was led to write his Summas to halt the threatened liquidation of Christian theology by Arabic interpretations of Aristotle ... indeed, the industry of Aquinas was due not to the love of Aristotle but to the fear of Averroes." 75 Thus, driven by this fear, the Latin Scholastic constructed the medieval "synthesis; "the Aristotelian-Averroistic heresies had been demolished and Ibn Rushd the 'infidel' had been humbled, and St. Thomas' followers celebrated his glory in this synthesis. So perceived, this conclusion is reflected in a medieval sketch that one medieval scholar reproduced in his book; the sketch is entitled "St. Thomas Aquinas overcoming Averroes," showing St. Thomas surrounded by angels and monks, displaying his "synthesis" to the vanquished Ibn Rushd lying at his feet. ${ }^{76}$

It was not to be so, however. During the 12th and 13th centuries Latin-Averroism had far-reaching consequences for medieval and modern social thought, hardly foreseeable by the medieval scholastics. It established "a tradition in which it became possible to question the status of religion" "77; and from the end of the 12th century to the end of the 16th century. Averroism remained the dominant school of thought, in spite of the orthodox reaction it created first among the Muslims in Spain and then among the Talmudists, and finally, among the Christian clergy. These were the centuries that witnessed revolutions in the evolution of social thought, with early Islamic sources always lurking in the background. As the Greek heritage "had aroused the great age of Arabic science and philosophy, so now it would excite the European mind and inquiry and speculation ... would crack stone after stone of that majestic edifice to bring this collapse of the medieval system in the fourteenth century, and the beginnings of modern philosophy in the ardor of the Renaissance." ${ }^{, 78}$ The results were monumental in Western history. Harold Nebelsick puts it rather succintly. He discusses the achievements of the Arab-Islamic scholars and how they "appropriated, appreciated and preserved Greek classical learning and built upon it,"79 and "thus, laid the foundations for a quite unprecedented revival of learning in Europe." $" 80$ And, "The results were the Renaissance in the thirteenth century, the Protestant Reformation in the sixteenth century, and eventually the rise of modern science in the seventeenth." ${ }^{\prime 1}$ Even in our own time, the contributions of those scholars, in the world of Islam and in the Christian West, represent the source of the most beneficent form of intellectual enlightenment. ${ }^{82}$

\section{SOURCES OF KNOWLEDGE TRANSMISSION}

The more critical question for us now is how this reservoir of Arab-Islamic knowledge, original and that built upon the Greek heritage, became available to Latin-Europe and which constituted the intellectual "roots" for Haskins' Medieval Renaissance as well as the subsequent Italian Renaissance? Before proceeding to this task, some relevant remarks are in order.

74 Sarton, II-2, 914.

75 Will Durant, The Story of Civilization: The Age of Faith, Vol. 4, 913, 954

76 See Walter Libby, An Introduction to the History of Science (New York:Houghton Mifflin Company, 1917), 55.

77 Norman Daniel, The Arabs and the Medieval West (London: Longman Group, 175-I), 107.

78 Will Durant, The Story of Civilization: The Age of Faith, Vol. 4, 913.

79 Harold Nebelsick, The Renaissance, The Reformation an $d$ the Rise of Science (Edinburgh, Scotland: T \& T,Clark, 1992), 5.

80 Ibid., ix.

81 Ibid., 9.

82 Majid Fakhri, Averroes, Aquinas, and the rediscovery of Aristotle in Western Europe, 7. 
The late George Sarton, in his book, A Guide to the History of Science (1952) has a fascinating chapter entitled, "The Tradition of Ancient and Medieval Science." Like Haskins, he is critical of "men of science whose retrospective insight does not go much deeper than the last century..." and who have "no idea of the vicissitudes of tradition." And he continues, "in order to understand the true meaning of scientific tradition and its value one has to look backward more deeply..." ${ }^{83}$ Then, overwhelmed by the contributions of the Arab-Islamic "giants" and their absorption and subsequent transmission of Greek classics, he emphasizes "the study of Arabic as the most promising method to increase our knowledge of Greek science." " ${ }^{\prime 4}$ Elsewhere, he talks in terms of the "Greek miracle" and the "miracle of Arabic science," and emphasizes the "birth of Islam as one of the most fruitful events in the history of mankind." ${ }^{, 85}$ As another scholar suggests, this "eastern impulse...the Arab intervention literally saved Greek knowledge from being destroyed, added to that knowledge, and handed it on a silver platter to Western Christendom."

Then, Sarton presents a graphical sketch of interconnecting lines, representing "history of traditions"- Greek, Egyptian, Babylonian, Iranian, and Indian, merging into the intermediate Arabic tradition. However, he asserts that "in spite of occasional contacts, Hindu culture, and even more so the Chinese culture, remained exotic, while the Arabic culture was inextricably mixed with the Latin one. When we try to explain our own culture we may leave out almost completely Hindu and Chinese developments, but we cannot leave out the Arabic ones without spoiling the whole story and making it unintelligible...The Arabic story helps us to understand our own because it is an intrinsic part of it" ${ }^{87}$ The "roots" of Western intellectual development, he insists, lie in the Arab-Islamic tradition, which was "from the 9th to the 11th century, the outstanding stream, and remained until the 14th century one of the largest streams of medieval thought." 88 "The Arabs were standing on the shoulders of their Greek forerunners, just as the Americans are standing on the shoulders of their European ones. There is nothing wrong in that." ${ }^{, 89}$ Indeed, the canvas of intellectual contours, extending over centuries, knows no geographic or cultural boundaries, as Sarton would argue. “... And if we have enough intelligence and grace we feel that we are like dwarfs standing upon the shoulders of giants." And several of the "giants of medieval times belonged to the Arab culture." Then, he enumerates the names of several ninth-twelfth century Arab "giants" and adds, the list "could be greatly extended." Sarton's sentiments are echoed by many others; for example, "No historical student of the culture of Western Europe can ever reconstruct the intellectual values of the later Middle Ages unless he possesses a vivid awareness of Islam looming in the background. ${ }^{91}$

${ }^{83}$ George Sarton, A Guide to the History of Science (Waltham, Mass: Chronica Botanica Press, 1952), 17-18.

${ }^{84}$ Ibid., 20.

${ }^{85}$ George Sarton, The Incubation of Western Culture in the Middle East, Library of Congress Lecture (March 1950). Washington, D.C.: U.S. Government Printing Office, 1951), 15 and 17.

${ }^{86}$ Eugene Myers, Arabic Thought and the Western World,, 67.

${ }^{87}$ George Sarton, A Guide to the History of Science, 27-30; also see Thomas Goldstein, Dawn of Modern Science (Boston, Mass.: Houghton Mifflin Company, 1988); Joseph McCabe, The Splendor of Moorish Spain (London: Watts and Company, 1975); R. W. Southern, The Making of the Middle Ages (New Haven, Conn.: Yale University Press, 1959); R. W. Southern,Western Views of Islam in the Middle Ages (Cambridge, Mass.: Harvard University Press, 1963) and others

${ }^{88}$ G eorge Sarton, A Guide to the History of Science, 27.

${ }^{89}$ Ibid., 28.

${ }^{90}$ Ibid., 28.

91 Pierce Butler, "Fifteenth Century of Arabic Authors in Latin Translation, "in The McDonald Presentation Vol., (Freeport, N.Y.: Books for Libraries, Inc., 1933), 63. 
As to transmission of knowledge, it might be noted that during any historical epoch the dominant global civilization tends to have its own almost natural, direct and indirect, cultural influences and pressures across its borders, as does the West (identified with the U.S.) presently and as did the Islamic civilization during its "golden age." Gomez mentions the "undeniable" fact of a "flourishing Arab civilization... and a European culture, whose pioneers openly confessed Arab superiority. The influence of the one on the other seems unavoidable... and far more wide than had been suspected." 92

We can identify several sources of "knowledge transfer" that was critical to "European Awakening," just as the recovery of the "Greek miracle" was critical to the "Arab-Islamic Awakening." ${ }^{.93}$ It might be noted that this "transfer" is quite parallel to what we observe today, from the West to the East, including the Islamic world, except that the earlier "knowledge reservoir," while built upon the Greek heritage, was "foundational," original, far diverse and the transfer process much longer in duration. Briefly we explain the following seven sources: travels, translations, oral tradition, trade and commerce, cultural diffusion, and perhaps most important, the Crusades, as well as some miscellaneous factors:

(1) Travels: During the 11th and early 12th centuries, several Latin-European scholastics traveled extensively to Arab-Islamic countries - to prosletyze and to learn; and they were especially successful in the latter. They learned Arabic, studied the works of Arab scholars, and brought back new knowledge. Among scores of such travelers, one was an eminent Englishman, Adelard of Bath, identified as "the pioneer student of Arabic science and philosophy in the twelfth century." ${ }^{, 94} \mathrm{He}$ goes out of his way to acknowledge methods of rational investigation to Arabs. ${ }^{95}$

During this period, "many students from Italy, Spain and southern France attended Muslim 'madrassas' in order to study mathematics, philosophy, medicine, cosmography, and other subjects, and in due course became candidates for professorships in the first Western universities established after the pattern of Muslim seminaries." 96 "All they had to do was cross the Pyrenees, swarm into the Muslim places of learning, take the volumes from their shelves, blow off the dust, and settle down to study Arabic ... the Islamic legacy proved ready and waiting just when it was needed the most." 97

And what about the intellectual inclinations of these "foreign" students? Latin-European priests were quite concerned; Alvaro, a Cordovan bishop lamented in the 9th century, all the young Christians who distinguish themselves by their talent, know the language and literature of the Arabs, read and study passionately the Arab books, and everywhere proclaim with a loud voice how admirable is that literature. And Alvaro had another anxiety; many of these students, he says, studied the Mohammadan theologians and

92 Eusebio Gomez, "Muslim Theology in its Bearing on Scholasticism," Clergy Review 6 (1933): 102, 105.

93 see George Makdisi, "Interaction between Islam and the West." Revue des studes Islamique. 44 (1976):287-309.

${ }^{94}$ Charles H. Haskins, The Renaissance of the Twelfth Century, 20.

95 Norman Daniel, The Arabs and the Mideaval West, 168.

96 M. M. Sharif, A History of Muslim Philosphy, 1367; also see Toby E. Huff, The Rise of Early Modern Science: Islam, China, and the West (New York: Cambridge University Press, 1993); Mehdi Nakosteen, History of Islamic Origins of Western Education, A.D. 800-1350 (Boulder, Col.: University of Colorado Press, 1964) and others.

97 Thomas Goldstein, Dawn of Modern Science, 93. 
philosophers, but not always, he adds, with a view to refuting them. ${ }^{98} \mathrm{He}$ also complained about their command of the Arabic language and their inability to write letters in Latin.

Further, based on the knowledge brought back by these students and other travelers, halls of new learning - patterned after their observations from the Islamic world (like many postwar colleges and universities in less-developed countries, patterned after U.S. institutions of learning) were established in numerous European cities, e.g., Naples, Salamanca, Oxford, Montepeller, Paris, and others; and several of these were specifically established to learn and assimilate Arab-Islamic scholarship. Further, the Council of Vienne (1311) established several schools of oriental languages, at the request of Raymond Lull (1232-1315). Lull had traveled widely in the Arab world, knew Arabic, and also wrote several works, with the objective of engaging in "missionary work among Saracens and Jews." 99 It was "in the 12 th century Europe discovered the wealth of Spain. Scholars descended upon Toledo, Cordoba, and Sicily and a flood of new learning poured up over Pyrenees to revolutionize the intellectual life of adolescent North"100; and "Sicily and the Italian south, still filled with

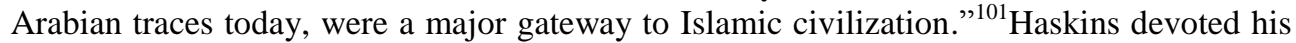
Studies in the History of Medieval Science (1924) "to study the first Christian scholars who went to the Moslem schools in Spain, and translated Arabic works on science entered Europe" "102; and "the pioneers of the new learning turned chiefly to Spain, and the Arabs of Spain represented the primary source for the new learning of Western Europe."103

(2) Translations: From about the 10th through the 13th centuries and beyond, there were translations en mass of Arab-Islamic scholarship into Latin. "The stream whereby the riches of Islamic thought were poured into the Christian West was by translations from Arabic into Latin." 104 This second "age of translations," much longer than the first (which relates to the Arabic translations of the Greek heritage during the 9th-10th centuries, took place in Spain, Sicily, Italy, and France. ${ }^{105}$ Some prominent "scholar-translators" were Constantine the African, Herman the German, Dominic Gundisilavi, John of Seville, Plato of Trivoli, William of Luna, Alfred of Sareshel, Adelard of Bath, and perhaps most important, Gerard of Cremona, and others. As to this source of transmission, Gerard-later to become Pope Sylvester - attributed "Europe's progressiveness to a large extent in a wise gathering of the fruits of Muslim culture."

Many of these translators could read and write Arabic, including the Franciscan monk, Roger Bacon (1214-1294), who, like Adelard of Bath and others, often acknowledged his debt to his Arab precursors; he would say, philosophy is the special province of the

98 Robert Briffault, The Making of Humnaity, 198, 217.

99 Will Durant, The Story of Civilization, The Age of Faith Vol. 4, 979.

${ }^{100}$ Ibid., 909.

${ }^{101}$ Thomas Goldstein, Dawn of Modern Science, 111.

${ }^{102}$ Joseph McCabe, The Splendor of Moorish Spain, 184.

${ }^{103}$ Charles H. Haskins, Studies in the Medieval Science (Cambridge, Mass.: Harvard University Press, 1924), 4-5.

${ }^{104}$ Will Durant, The Story of Civilization, The Age of Faith vol. 4, 910.

${ }^{105}$ Eugene A. Myers, Arabic Thought and the Western World; Charles H. Haskins, "Science at the Court of Emperor Frederick II." American History Review 27.4 (July, 1922): 669-694; Aziz Ahmad, A History of Islamic Sicily

(Edinburgh, U. K.: Edinburgh University Press, 1975); M. I. Finley, Denis M. Smith and Christopher Dugan (Editors). A History of Sicily (New York: Viking Penguin, Inc., 1967); Abulafia, David. Frederick II: A Medieval Emperor (London: The Penguin Press, 1988); and others.

${ }^{106}$ Sarton, II, 279. 
unbelievers (Saracens); we have it all from them ${ }^{107}$; Albertus Magnus, St. Thomas mentor, was also known to have similar views. And, "Roger Bacon was no more than one of the apostles of Muslim science and method to Christian Europe; and he never wearied of declaring that knowledge of Arabic and Arabian science was for his contemporaries the only way to true knowledge." "108 These "scholars from Europe were desperate to make all known scientific and technical books available in translation...and they produced Latin translations of not only of Greek works but also of original works by Arab scholars...."109 Moreover, "The truth is that during the $12^{\text {th }}$ century hundreds of students, Jewish and Christian, were busy translating Arabic scientific treatises, and Christian seekers of wisdom went from every country in Europe to study in Spain." ${ }^{\prime 10}$. Indeed, such contacts persuade Gordon Leff to suggest that 13th century was the "century of synthesis" and "Intellectually, the difference between 12th and 13th century was isolation from the Islamic world and contact with it." 111 Further, during 14th and 15th centuries, the European scholastics and others were also indirectly influenced by the writings of their European predecessors and contemporaries whose discourses had assimilated Arab scholarship. ${ }^{12}$ Clearly, those influences reached numerous European scholars even beyond the 15 th century.

And it deserves to be noted that while translations and other sources were engaged in providing the "roots" of European civilization, some in Islamic Spain were concerned about plagiarism, for an Andulisian Moslem of the late eleventh century, Ibn Abdun, alludes to the translating activity going on in Spain with a warning addressed to the faithful: you must not sell books of science to Jews and Christians ... because it happens that they translate these scientific books and attribute them to their own people and to their bishops, when they are indeed Moslem works. ${ }^{13}$ Briffault suggests something similar concerning Arabic discoveries and inventions, for "discussions as to who are the originator of the experimental method, like the fostering of every Arabic discovery or invention on the first European who happens to mention it, such as the invention of the compass to a fabulous Flavio Gioji of Analfi, of alcohol to Arnold of Villeneuve, of lenses and gunpowder to Bacon or Schwartz, are part of the colossal misrepresentation of the origins of European civilization. ${ }^{114}$

(3) Oral Tradition: A third important link was through the oral tradition-something for which documentation is not as readily possible. While tracing such links, Chejne argues that "Al-Andalus was a fertile ground for cultural interaction and a natural link between Arabic, medieval Spanish, and European thought; also the process of transmission, particularly oral transmission, was an important factor, and that this is proven by internal

\footnotetext{
${ }^{107}$ Quoted by R. W. Western Views of Islam in the Middle Ages, 59.

${ }^{108}$ Robert Briffault, The Making of Humnaity, 201.

${ }^{109}$ Jean Gimpel, The Medieval Machine: The Industrial Revolution of the Middle Ages (New York: Holt, Rinehart and Winston, 1976), 175,178.

${ }_{110}^{110}$ Joseph McCabe, The Splendor of Moorish Spain, 243.

${ }^{111}$ Gordon Leff, Medieval Thought: St. Augustine to Ockham (Chicago, Illinois: Quadrangle Books, Inc. 1958), 141.

${ }^{112}$ A. C. Crombie, Medieval and Early Modern Science (Cambridge, Mass: Harvard University Press, 1963), 30.

${ }^{113}$ Marie-Therese d'Alverny, "Translations and Translators," in Renaissance and Renewal in the Twelfth Century. Edited by Robert L. Benson and Giles Constable. (Cambridge, Mass.: Harvard University Press, 1982), 440.

${ }^{114}$ Robert Briffault, The Making of Humanity, 201.
} 
literary evidence in both Arabic and Western materials. ${ }^{115}$ Further, Al-Andalus provided a "cultural environment in which people of different religions and ethnic backgrounds lived together for centuries. They were bound by geographical proximity, uninterrupted contact through marriage, conversion, commerce, and travel, all of which are conducive to intellectual interaction and borrowing. It was a melting pot and a laboratory, and it brought East and West much closer together."116 And after the reconquest, "the Spanish Christians along with their supporters from abroad, came into immediate contact with Muslims and Arabized Jews and Christians, who entered the service of their new masters in the following capacities: administrators, tax-collectors, advisers, interpreters, and even as military commanders. Their role in the transmission of ideas, within and outside Spain was enormous." "117 Further, "oral transmission (was) achieved by a long and permanent contact between Muslims and Christians ... bilingualism in Spain was common. Eight or more centuries of such an intimate contact is, in itself, quite persuasive an argument for a cultural interaction and continuity ... It is from this vantage point that more weight should be given to oral transmission, which often extended well beyond the frontiers of Spain.",118

In somewhat the same context, though the point is also relevant to other avenues of transmission, Hoyt suggests that "Because of the nearness to Europe - that mingling of languages beneath the veneer of Arabic and that contact of the Western Arabs with Europeans - there came a transmission of the culture of Islam to the West. It might not have been possible under any other circumstances., ${ }^{, 19}$ And in discussing such influences, Gomez says, political influence was still more noticeable. The reigning house of Argon and Castile became allied by marriage with families of Moorish Kings. Moslem fashions and habits were introduced in every department of private life. ${ }^{120}$

(4) Trade and Commerce: Another channel through which ideas flowed to Europe was extensive trade and commercial activities before, during and after the Crusades. Several writers have shown how trade was carried on between the Arab world through Russia to Poland, the shores of Baltic seas, to Scandinavia, to north-central Europe and even Iceland. ${ }^{121}$ With trade accompanied the diffusion of business practices common in the Islamic world, incentives for economic gain and improvement, as well as desire to own the fruits of one's labor. "Arab money was in use in the Christian kingdoms of the north, which

${ }^{115}$ Anwar Chejne, "The Role of Al-Andalus in the Movement of Ideas Between Islam and the West, " in Islam and the West: Aspects of Intercultural Relations. Edited by Khalil I. Semaan, (Albany, N.Y.: University of New York Press, 1980), 111.

${ }^{116}$ Anwar Chejne, "The Role of Al-Andalus in the Movement of Ideas between Islam and the West," in Islam and the West: Aspects of Intercultural Relations, 113; also see Geoarge Sarton, The Incubation of Western Culture in the Middle East. Library of Congress Lecture (March 1990),13.

${ }^{117}$ Anwar Chejne, "The Role of Al-Andalus in the Movement of Ideas between Islam and the West," 117-118.

118 Ibid.

119 Edwin P. Hoyt, Arab Sciences: Discoveries and Contributions (New York: Thomas Nelson, Inc., Publishers, 1975), 109.

${ }^{120}$ Eusebio Gomez, "Muslim Theology in its Bearing on Scholasticism," 102.

${ }^{121}$ see M. A. Cook, "Economic Developments," in The Legacy of Islam, 2nd Edition. Edited by Joseph Schacht and C.E. Bosworth (Oxford, England: The Clarendon Press, 1974); John W. Draper, A History of the Intellectual Development of Europe, 2 Volumes, (New York: Harper \& Row Publishers, 1876 and 1904); Herbert Heaton, Economic History of Europe, Revised Edition (New York: Harper \& Brothers, Publishers, 1948); Phillip K. Hitti, The Arabs: A Short History (Princeton, N.J.: Princeton University Press, 1943) for example. 
for nearly four hundred years had no coinage other than Arabic or French." ${ }^{122}$ Further, in addition to coins, numerous techniques and methods of commerce, as well as the spirit of enterprise and adventure, spread to Europe. ${ }^{123}$ "Muslim writers of this period do tend to be more sympathetic to mercantile activity than those of Christian Europe... much of early Islamic literature was in fact written in a mercantile environment." 124 The spirit of enterprise was further nurtured by Arab-Islamic scholars for whom the Islamic Scriptures mandated economic pursuits as part of the "calling." 125 Factories were established to produce silk and textiles, as well as other goods. "In Spain, they were in Almeria, Murcia, Seville, Granada, and Malaga...Even in Sicily, where the Arabs ruled for a long time, the tradition of state factories was preserved and in Palermo the regium ergasterium produced finely woven silk down to the thirteenth century." "126

Relatedly, there is the well-known but controversial "Pirenne thesis" (proposed by the celebrated Belgian historian, Henri Pirenne, 1862-1935), which was based "upon the extent and nature of trade in the Mediterranean and in Western Europe from the fifth to the ninth centuries." 127 Pirenne argued that "it was the impact of Islam in the 7th and 8th centuries which, by destroying the unity of the Mediterranean, ended the Roman world and led to a strikingly different civilization in the Carolingian era." 128 Pirenne was most emphatic: "Without Islam the Frankish Empire would probably never have existed and Charlemagne, without Mohamet, would be inconceivable."129 This thesis attributed a central role to Islam in European evolution, something that was not viewed favorably by historians, and subsequently, almost by consensus it seems, the Pirenne "heresy" has since been denigrated.

As to this source of transmission, while recognizing how ideas flow with trade and commerce, Haskins cautions us, however, concerning the subtlety of such influences. He says, "such results of trade are likely to be intangible and to have few immediate traces...If the intercourse of the Mohammadan East is mainly concerned with the wares of commerce, we must remember that it has been impossible to separate the interchange of wares from the interchange of knowledge and ideas." 130

(5) Diffusion of Institutions: Another source of transmission was through cultural diffusion of institutions and practices into European societies, as trading and commercial links developed. Udovitch reports his discovery of a 15th century commenda ("mudharibah" in Arabic, a written contract whereby one partner provides financing, the other manages the business; both share risk and profit as agreed) between a Venetian and an Arab merchant in

${ }^{122}$ Phillip K. Hitti, The Arabs: A Short History, 144.

${ }^{123}$ M. A. Cook, "Economic Developments," in The Legacy of Islam, 2nd Edition. Edited by Joseph Schacht and C.E. Bosworth, 219; also see Hitti, The Arabs: A Short History especially chapter 11.

${ }^{124}$ M. A. Cook, "Economic Developments," in The Legacy of Islam, 2nd Edition. Edited by Joseph Schacht and C.E. Bosworth, 226.

${ }^{125}$ See S. M. Ghazanfar, "Capitalistic Tradition in Early Islamic Civilization," Journal of Oriental and African Studies (Athens, Greece) 18, (2009): 139-157.

${ }^{126}$ Subhi Y. Labib, "Capitalism in Medieval Islam." Journal of Economic History. 29 (1969):87.

${ }^{127}$ Alfred F. Havighurst, Alfred F. (Editor). The Pirenne Thesis: Analysis, Criticism and Revision (Lexington, Mass.: D.C. Heath \& Company, 1969), viii.

${ }^{128}$ Ibid.

${ }^{129}$ Quoted by Havighurst in The Pirenne Thesis: Analysis, Criticism and Revision, iii.

${ }^{130}$ Charles H. Haskins, The Renaissance of the Twelfth Century, 64. 
Alexandria. The tradition of the commenda goes back to the days of the Prophet $S A W .^{131}$ Thus, the commenda and other partnership contracts were indigenous to the Arab-Islamic world and spread to Latin Europe through contacts and writings of Arab-Islamic scholars and jurists. Similarly, the emergence of various other instruments and institutions facilitated the development of commerce and trade in Europe, such as bills of exchange (siftajah), letter of credit (hawala), specialized trading centers (funduq), and an early private bank (ma'una). ${ }^{132}$ "Of great significance for the medieval capitalistic trade of Islam was the establishment of the funduqs, specialized large-scale commercial institutions and markets which developed into virtual stock exchanges" $" 133$ Further, Kramers traces the emergence of a debt instrument and mentions "the Arabic word sakk, from which the modern word cheque has been derived." He also traces the Arabic origin of several other commercial terms and discusses the "manifold ways in which commercial relations led to close cooperation between Muslims and Christians." 134 The origins of banking, among Muslims and Jews, is traced by one scholar in early medieval Islam, the term for early bankers being jahbadh, or "a money expert, experienced in most intricate affairs, very well versed in matters of cash." 135

Further, given their worldwide trading links, the merchants of early Islamic world "became indispensable middlemen because of their contact with the West-either through the Mediterranean or the Baltic-and also the Far East." ${ }^{136}$ And, "everywhere that Islam entered, it activated business life, fostered an increasing exchange of goods, and played an important part in the development of credit." "137 And, according to Briffault, "the English fiscal system, like the name it bears today-the Exchequer-was derived from Muslim Sicily." 138 Relatedly, and quite significantly, the prolonged contacts with the much advanced cultural environment of the Islamic world induced a powerful "demonstration effect" to its spheres of European contacts whereby not only commercial-technical knowledge spread, but also the tastes for a variety of consumer goods common in the Islamic regions. ${ }^{139}$

In the same general context, one prominent economic historian traces the evolution of $15^{\text {th }}$ century European Renaissance and, commenting on the 'disintegration of Thomistic reasoning,' he mentions two significant streams emanating from the Arab-Islamic world. Thus, "one stream originating in Italian cities, which in the wake of Crusades had established relations with the traders of the Near East and had adopted various institutions and processes which were at variance with the rigid patterns of the medieval social and economic organization. The other, far more important, stream started within the body of the

${ }^{131}$ Subhi Y. Labib, "Capitalism in Medieval Islam," 91.

${ }^{132}$ see Subhi Y. Labib, "Capitalism in Medieval Islam," Journal of Economic History. 29 (1969): 79-96; J. H. Kramers, "Geography and Commerce," in The Legacy of Islam. Edited by Sir Thomas Arnold and Alfred Guillaume, (Oxford, England: The Clarendon Press, 1931)

${ }^{133}$ Subhi Y. Labib, "Capitalism in Medieval Islam," 85.

${ }^{134}$ J. H. Kramers, "Geography and Commerce," in The Legacy of Islam, 102.

${ }^{135}$ Walter Fischel, "The Origins of Banking in Medieval Islam: A Contribution to the Economic History of Jews in Baghdad in the Tenth Century," Journal of Royal Asiatic Society. 3: (1933):341; also See S. M. Ghazanfar, "Capitalistic Tradition in Early Islamic Civilization,” Journal of Oriental and African Studies (Athens, Greece) 18, (2009): 139-157.

${ }^{136}$ Subhi Y. Labib, "Capitalism in Medieval Islam, "80.

${ }^{137}$ Ibid.

${ }^{138}$ Robert Briffault, The Making of the Humanity, 212; Arabic equivalent word is "Qaid"

${ }^{139}$ See M. A. Cook, "Economic Developments," in The Legacy of Islam, 219; also see Hitti, The Arabs: A Short History. 
Scholastic Theologians, who derived their intellectual armory from the works of the Arabian philosophers." 140

(6) The Crusades: Another major source of transmission-one that runs about parallel with others - has to be the Crusades that lasted about two centuries, from 1095 to 1292 . The Crusades have been interpreted variously:

(i) a holy war directed by God through His Vicar on earth, the Holy Pontiff;

(ii) an outburst of fanaticism and bigotry, as viewed by rationalist philosophers;

(iii) a migratory movement from West to East in search of more opulent terrain; and

(iv) Europe's eastward expansion, a form of colonization and imperialism, necessitated by the pressures of growing population and meager resources. "In the century under review French and Spanish feudal barons extended their domains south of the Pyrenees at the expense of the Moslems....after all the [Crusades represented the] most influential expansionary movement of the 12th century." ${ }^{141}$ Conscious of such pressures, "Pope Urban II in his address of [November $27^{\text {th }}$ ] $1095 \mathrm{AD}$, referred to Palestine as a land where rivers of milk and honey flowed freely." ${ }^{142}$ Regardless, however, their central importance, as noted earlier, is "not because they facilitated cultural interchange (as virtually all historians now agree they did not), but because they helped to shape European attitudes, feelings and values. The achievements of the twelfth century renaissance owe a great deal to the Crusades...." ${ }^{\text {"143 }}$ As for the influences through "cultural interchange," a dissenting perspective becomes evident from Atiya and others." 144

The Crusades brought East and West more closely together, notwithstanding the violent fanaticism they engendered. The Crusaders who settled in the Levant were in daily contacts with the Arabs upon whom they depended for their needs of every-day life. Furthermore, Arabs and Franks were drawn together at popular gatherings, festivals, tournaments, and other public events. Fanaticism was softened and gave room to mutual tolerance and appreciation. The difference between the resident

${ }^{140}$ Karl Pribram, A History of Economic Reasoning (Baltimore, Maryland: The Johns Hopkins University Press, 1983), 21.

${ }^{141}$ Hilmer C. Krueger, "Economic Aspects of Expansionary Europe," in Twelfth Century Europe and the Foundations of Modern Society, Edited by Marshall Claggett, Gaines Post and Robert Reynolds, (Madison, Wisconsin: University of Madison Press, 1961), 59-60; also see Robert Bartlett, The Making of Europe: Conquest, Colonization, and Cultural Change (Princeton, N.J.: Princeton University Press, 1993).

${ }^{142}$ Aziz S. Atiya, Crusades, Commerce and Culture (Bloomington, Ind. Indiana Press, 1965), 18; also see Aziz S. Atiya, Atiya, "The Crusades: Old Ideas and New Conceptions," Journal of World History 2 (1954):470-7; Hilmer C. Krueger, Hilmer C. "Economic Aspects of Expansionary Europe," in Twelfth Century Europe and the Foundations of Modern Society.

${ }^{143}$ Stephen C. Ferruolo, "The Twelfth Century Renaissance," in Renaissances Before the Renaissance: Cultural Revival of Late Antiquity and the Middle Ages, 136.

${ }^{144}$ See Aziz S. Atiya, Crusades, Commerce and Culture (Bloomington, Ind. Indiana Press, 1965), 18; also see Aziz S. Atiya, Atiya, "The Crusades: Old Ideas and New Conceptions." Journal of World History 2 (1954):470-7; also Philip K. Hitti, An Arab-Syrian Gentleman and Warrior in the Period of the Crusades: Memoirs of Usamah Ibn-Munqidh. Translated from Original. ( New York: Columbia University Press, 1929); Francisco Gabrieli, Arab Historians of the Crusades (Berkeley, Calif.: University of California Press, 1969); Nejla Izzedin, The Arab World: Past, Present, Future (Chicago, Illinois: Henry Regnery Company, 1953); Amin Maalouf, The Crusades through Arab Eyes (Translated by Jon Rothschild). (New York: Schocken Books, 1985); and others. 
Crusaders and new arrivals from Europe in their attitude toward the Muslims is noted in contemporary Arab sources, as for example, The Memoirs of Usamah Ibn Munqidh. 145

Moreover, the Crusaders found in the Levant a culture in most respects superior to their own. Life on the whole was richer, fulfilling, and more varied. The land produced a rich variety of crops and fruits, many unknown to the Europeans. Markets and bazaars were stacked with all manner of goods, some imported from distant lands. The influence of contacts through the Crusades is evident in the public steam baths which began to make their appearance in Europe, and the foundation of hospitals on the patterns of those established by the Orders of the Holy Land. The Crusaders were "the strongest influence on the development of medieval trade and industry. ${ }^{146}$

They stimulated the activities of the great commercial city-states of Italy: Venice, Genoa, Pisa, and others. They promoted "the capitalistic cycle of capital, investment, profit, and reinvestment of profit for further profit and capital and initiated a money economy which threatened and certainly modified the old land economy of Western Europe." ${ }^{147}$ And, above all, "the Crusades stimulated the intellectual life of Europe and its literary output by broadening the horizons of knowledge and imagination; they ... were an inspiration to artists, poets, and singers for many generations." 148

(7) Miscellaneous Factors: It should be clear that the various sources of transmission that we have discussed operated more or less simultaneously. However, the "turning point" to Europe's Enlightenment through Arabic-Islamic knowledge involved numerous other factors as well. We can note five such relatively minor factors:

(i) Monasteries: These were the great literary centers, having libraries with collections of translated works; as oldest type of intellectual centers, "for centuries, monasteries stood like scattered islands in an area of ignorance. ${ }^{149}$

(ii) Cathedral Chapter Schools: During the 11th and 12th centuries, the cathedral schools were at their peak, often drawing excellent teachers who had traveled to Spain and Sicily and brought back Arab-Islamic knowledge to impart to their students. Alongside the monastery as a center of culture was the cathedral school...to them was brought most of the science and philosophy recovered by the West from the Byzantines and the Saracens. ${ }^{150}$

${ }^{145}$ Nejla Izzedin, The Arab World: Past, Present, Future, 41.

${ }^{146}$ Hilmer C. Krueger, "Economic Aspects of Expansionary Europe," in Twelfth Century Europe and the Foundations of Modern Society, 72.

${ }^{147}$ Ibid., 73.

${ }^{148}$ Nejla Izzedin, The Arab World: Past, Present, Future, 42.

149 Frederick B. Artz, The Mind of the Middle Ages, AD 200-1500: An Historical Survey (New York, N.Y.: Alfred A. Knopf Publishers, 1953), 229.

${ }^{150}$ Frederick B. Artz, The Mind of the Middle Ages, AD 200-1500: An Historical Survey, 229; also see Josiah C. Russell, Twelfth Century Studies, (New York: AMS Press, 1978); Josiah C. Russell, "Hereford and Arabian Science in England about 1175-1200," ISIS. 18:1 (July, 1932) 14-25; Mary C. Welborn, "Lotharingia as a Center of Arabic Scientific Influence in the Eleventh Century," ISIS. 16 (1931):188-99; Diane P. Thompson, "Paradigm Lost: Western Civilization and the Orient Unexpressed," Northern Virginia Review, no.10 (Fall, 1995): 5-8; James W. Thompson, "The Introduction of Arabian Science into Lorraine in the Tenth Century," ISIS. 38:12 (May, 1929.) 184-193. 
(iii) Royal Courts: These courts often included men of learning. The Norman court of Palermo (Sicily), especially under Emperors Roger II and Frederick II a century later-was as brilliant and refined a center of Arab learning as any in the Middle East or in Spain. And Frederick II used to send for Arab savants and translators to come to his court... where Arabic was not only one of the four official languages but the monarch's native language. ${ }^{151}$ And in his court, the Greek element is of little significance ... on the other hand, Arabic influence was stronger... ${ }^{152}$ "Arabic was as widely spoken as any other language in some of the courts of Christian Kings, and their doctors, counselors, and courtiers were often Arabs."153

(iv) Missionarie: Islamic culture was known in Europe partly through the commercial contacts, sometimes through the travels of Christian missionaries in the East ..."154; and "the Mendicant Orders, Franciscan Gray Friars, Dominican and Preaching Brothers sent forth as her representatives, contributed in no small degree to these triumphs in natural history" ${ }^{\prime 55}$; his reference is to missionary contacts with the "Saracens;" and

(v) Cities: As Henri Pirenne had argued, many European cities and towns, especially in South France and Italy, originated in the footsteps of trade ... and this trade chiefly depended upon close encounters with the Mediterranean Arab-Islamic world; 'faubourg', communities of merchants outside the castle walls of cities, evolved in this environment. And the economic factors and forces existent and operative in the expansion of the city and plains were significantly present in the more extensive, overseas countries into the Near East. Similarly, these economic forces were at work for a long time before the 12 th century. ${ }^{156}$

\section{SOME CONCLUDING OBSERVATIONS}

Given the broad nature of our topic, this paper has covered several interrelated themes. First, I commented on the "lost paradigm" of Western literary history, replete with "gaps" in just about every field of knowledge, with little or no acknowledgment of the critical role of the Islamic civilization. Secondly, after noting the nature and impact of the influence of Islamic scholarship, I discussed the influence of a few prominent Islamic scholars-Ibn Rushd's role a bit more in detail, for his works, once transmitted and assimilated, generated unprecedented upheaval—and transformation--in Latin-European social thought. This was followed by coverage of the various sources through which knowledge from the early Islamic world transmitted to the Latin-West. Indeed, the Western civilization is the product of Judeo-Christian-and-Islamic heritage, with Greeks in the background-a very mixed ancestry, indeed.

${ }^{151}$ Maria Rosa Menocal, The Arabic Role in Medieval Literary History: A Forgotten Heritage (Philadelphia: University of Pennsylvania Press, 1987), 74-75.

${ }^{152}$ Charles H. Haskins, "Science at the Court of Emperor Frederick II," American History Review 27.4 (July, 1922$)$ ) 671.

${ }^{153}$ Eusebio Gomez, "Muslim Theology in its Bearing on Scholasticism," 102.

${ }^{154}$ Jean Sauvaget, (Editor). Introduction to the History of the Muslim East: A Bibliographic Guide. 2nd Edition (recast by Claude Cahen) (Berkeley, Calif.: University of California Press, 1965), 228.

${ }^{155}$ Paul Laroix, Science and Literature in the Middle Ages and the Renaissance ( New York: Frederick Ungar Publishing Company, 1878 reprinted 1964), 113.

${ }^{156}$ Hilmer C. Krueger, "Economic Aspects of Expansionary Europe," in Twelfth Century Europe and the Foundations of Modern Society, 69. 
Having pursued these tasks, we can conclude with noting additional corroborative comments from three eminent medievalists:

(1) We are so accustomed to regard our culture as essentially that of the West that it is difficult for us to realize that there was an age when the most civilized region of Western Europe was the province of an alien culture (i.e., Islam)...At a time when the rest of Western Europe was just emerging from the depths of barbarism, the culture of Moslem Spain had attained complete maturity and surpassed even the civilization of the East in genius and originality of thought...All of this brilliant development of culture is completely ignored by the ordinary student of medieval European history. It is as though it were a lost world which had no more to do with the history of our past than the vanished kingdom of Atlantis. ${ }^{157}$

(2) George Sarton calls the Arab-Islamic impact on Europe as "the miracle of Arabic science, using the word miracle as a symbol of our inability to explain achievements which were almost incredible. There is nothing like it in the whole history of the world...Some historians have tried to belittle those immense achievements by claiming that there was nothing original in them and that the Arabs were nothing but imitators. Such a judgment is all wrong... The achievements of the Arabic-speaking people between the ninth and twelfth centuries are so great as to baffle our understanding. ${ }^{158}$

(3) Islam is the parent that beget and nourished European civilization...We may be sure that those who accuse Moslem scholars of lack of originality and of intellectual decadence have never read Averroes or looked into al-Ghazali, but have accepted second-hand judgments. The presence of doctrines of Islamic origins in the very citadel of Christianity, the Summa of Aquinas, is a sufficient refutation of the charge of lack of originality and sterility. ${ }^{159}$

Yet, most contemporary literary discussions of the evolution of social thought continue to reflect the persistent and stubborn Eurocentric "blind spot." Thus, for the sake of ensuring "continuity and change," as Haskins and others would want, and for the sake of doctrinal objectivity that is incumbent upon all scholars, there is this plea from an eminent Yale University scholar: Can the Western Europeans somehow overcome the great difficulty in considering the possibility that they are in some way seriously indebted to the Arab world, or that the Arabs were central to the making of medieval Europe ${ }^{160}$ Resistance is deep-rooted, however.

And I should add that in the post-9/11, Islamophobic environment of the West, there are wellorganized forces that are nurturing this resistance even deeper and stronger than ever. Thus, the need for "the dialogue of civilizations" that I noted at the outset from Kofi Annan's 1999 speech is ever greater - the dialogue of the civilized, rather than the Hungingtonian "clash" of the uncivilized. That is the contemporary civilizational challenge, to be pursued with humility, not arrogance, by all; and there lies also the enormous potential for universal good.

${ }^{157}$ Christopher Dawson, "The Origins of the Romantic Tradition," The Criterion 11 (1932): 230-231.

${ }^{158}$ George Sarton, The Incubation of Western Culture in the Middle East. Library of Congress Lecture (March 1950), $1951,27,29,35$.

${ }^{159}$ Alfred Guillaume, "Philosophy and Theology," in The Legacy of Islam. Edited by Sir Thomas Arnold and Alfred Guillaume, (Oxford, England: The Clarendon Press, 1931); quoted in Bertram Thomas, 190.

${ }^{160}$ Maria Rosa Menocal, The Arabic Role in Medieval Literary History: A Forgotten Heritage, xii-xiii. 
In a more immediate sense, however, there are transformational challenges for the Islamic world. Rationalism from early Islam sparked the Latin-European exit from its Dark Ages and contributed to the making the modern West. Given the state of affairs of the contemporary Islamic world, here is a plea, shared globally by numerous Muslim scholars: Can rationalism of early Islam come full circle? Can there be a renewal of Ijtihaad that can launch another "Islamic Awakening," more dynamic than that of the Golden Age? Can the Islamic world move forward to the $21^{\text {st }}$ centurymodernizing, yet not necessarily 'westernizing,' without losing the essence of its pristine Islam? That indeed is the challenge for Muslim intellectuals. And there lies also the great potential. 


\section{SELECTED BIBLIOGRAPHY}

1. Abulafia, David. Frederick II: A Medieval Emperor. London: The Penguin Press, 1988.

2. Afnan, Soheil M. Avicenna: His Life and Works. London: George Allen \& Unwin, 1958.

3. Agius, Dionisus A. and Richard Hitchcock (Editors). The Arab Influence in Medieval Europe. Reading, U.K.: Ithaca Press, 1994.

4. Ahmad, Aziz. A History of Islamic Sicily. Edinburgh, U.K.: Edinburgh University Press, 1975.

5. d'Alverny, Marie-Therese. "Translations and Translators." In Renaissance and Renewal in the Twelfth Century. Edited by Robert L. Benson and Giles Constable. Cambridge, Mass.: Harvard University Press, 1982.

6. Amin, Samir. Eurocentricism (translated into English by Russell Moore). New York, N.Y.: Monthly Review Press, 1989.

7. Arnold, Thomas and Alfred Guillaume (Editors). The Legacy of Islam. Oxford, England: Oxford University Press, 1931.

8. Atiya, Aziz S. "The Crusades: Old Ideas and New Conceptions.” Journal of World History 2 (1954):470-7

9. Atiya, Aziz S. Crusades, Commerce, and Culture. Bloomington, Ind. Indiana University Press, 1962.

10. Aquinas, St. Thomas. Summa Theologica, 3 Volumes. New York, N.Y.: Benziger Brothers, 1947.

11. Artz, Frederick B. The Mind of the Middle Ages, AD 200-1500: An Historical Survey. New York, N.Y.: Alfred A. Knopf Publishers, 1953.

12. Bammate, Haidar. Muslim Contributions to Civilization. Takoma Park, Md.: Crescent Publications, 1962.

13. Bartlett, Robert. The Making of Europe: Conquest, Colonization, and Cultural Change. Princeton, N.J.: Princeton University Press, 1993.

14. Benson, Robert and Giles Constable (Editors). Renaissance and Renewal in the Twelfth Century (Proceedings: 1977 Conference in commemoration of Charles H. Haskins' contributions). Cambridge, Mass.: Harvard University Press, 1982.

15. Bernal, Martin. Black Athena: The Afroasiatic Roots of Classical Civilization; Vol.I, The Fabrication of Ancient Greece, 1785-1985. New Brunswick, N.J.: Rutgers University Press, 1987.

16. Bratton, Fred G. Maimonides: Medieval Modernist. Boston, Mass.: Beacon Press, 1967.

17. Briffault, Robert. The Making of Humanity. London: George Allen \& Unwin Ltd.; and New York: The Macmillian Company,1919. 
18. Butler, Pierce. "Fifteenth Century of Arabic Authors in Latin Translation." In The McDonald Presentation Vol. 63-70. Freeport, N.Y.: Books for Libraries, Inc., 1933.

19. Callus, D.A. Robert Grosseteste: Scholar and Bishop. Oxford, England: The Clarendon Press, 1969.

20. Chejne, Anwar. "The Role of Al-Andalus in the Movement of Ideas Between Islam and the West." In Islam and the West: Aspects of Intercultural Relations. Edited by Khalil I. Semaan. Albany, N.Y.: University of New York Press, 1980.

21. Claggett, Marshall, Gaines Post, and Robert Reynolds (Editors). Twelfth Century Europe and the Foundation of Modern Society (Symposium Proceedings, held 1957). Madison, Wis.: University of Wisconsin Press, 1961.

22. Cobb, Stanwood. Islamic Contributions to Civilization. Washington, D.C.: Avalon Press, 1963.

23. Cook, M.A. "Economic Developments." In The Legacy of Islam, 2nd Edition. Edited by Joseph Schacht and C.E. Bosworth. Oxford, England: The Clarendon Press, 1974.

24. Copelston, F.C. A History of Medieval Philosophy. New York: Harper \& Row, Publishers, 1972.

25. Crombie, A.C. Medieval and Early Modern Science. Cambridge, Mass: Harvard University Press, 1963.

26. Daniel, Norman. The Arabs and the Medieval West. London: Longman Group, 1975-I.

27. Daniel, Norman. The Cultural Barrier: Problem in the Exchange of Ideas. Edinburgh, England: Edinburgh University Press, 1975-II.

28. Dawson, Christopher. "The Origins of the Romantic Tradition." The Criterion, 11 (1932):222-248.

29. Dawson, Christopher. The Making of Europe: An Introduction to the History of European Unity. New York: Sheed and Ward, 1952.

30. Dawson, Christopher. The Formation of Christianity. New York: Sheed and Ward, 1967.

31. Draper, John W. A History of the Intellectual Development of Europe, 2 Volumes. New York: Harper \& Row Publishers, 1876 and 1904.

32. Dunlop, D.M. Arab Civilization to A.D. 1500. New York: Praeger Publishers, 1971.

33. Durant, Will. The Story of Civilization: The Age of Faith, Vol.4. New York: Simon \& Schuster, 1950.

34. Farrukh, Omar A. The Arab Genius in Science and Philosophy (translated by John B. Hardie). Washington, D.C.: American Council of Learned Societies, 1954.

35. Farsi, Nabih A. (Editor). The Arab Heritage. New York: Russell and Russell, Inc., 1963.

36. Ferrueolo, Stephen C. "The Twelfth Century Renaissance” In Renaissances Before the Renaissance: Cultural Revival of Late Antiquity and the Middle Ages. Edited by Warren 
Treadgold. Stanford, Calif.: Stanford University Press, 1984.

37. Finley, M.I., Denis M. Smith and Christopher Dugan (Editors). A History of Sicily. New York: Viking Penguin, Inc., 1967.

38. Fischel, Walter. "The Origins of Banking in Medieval Islam: A Contribution to the Economic History of Jews in Baghdad in the Tenth Century" Journal of Royal Asiatic Society. 3: (1933):339-352

39. Flint, Robert. History of the Philosophy of History. New York: Charles Scribner's Sons, 1894.

40. Gabrieli, Francisco. Arab Historians of the Crusades. Berkeley, Calif.: University of California Press, 1969.

41. Ghazanfar, S.M. 'Scholastic Economics and Arab Scholars: The 'Great Gap' Thesis Reconsidered" Diogenes: International Review of Humane Sciences 154 (April-June, 1991): 117-40.

42. Ghazanfar, S.M. 'History of Economic Thought: The Schumpeterian 'Great Gap,' The 'Lost' Arab-Islamic Legacy, and the Literature Gap" Journal of Islamic Studies 6.2, Oxford University Press, (1995): 234-253.

43. Ghazanfar, S.M. 1994. "Post-Greek/Pre-Renaissance Economic Thought: Contributions of Arab-Islamic Scholastics during the 'Great Gap' Centuries.” Paper presented at the 1994 History of Economics Society Conference, Babson, Mass. Forthcoming (1998). Research in History of Economic Thought and Methodology

44. Ghazanfar, S.M. and A. Azim Islahi. "Economic Thought of an Arab Scholastic: Abu Hamid Al-Ghazali (AH 450-505/AD 1058-1111)" History of Political Economy 22.2 (1990): 381-403.

45. Ghazanfar, S.M. and A. Azim Islahi. 1992. "Explorations in Medieval Arab-Islamic Economic Thought: Some Aspects of Ibn Taimiyah's Economics." In Perspectives on the History of Economic Thought, Vol.VII: Perspectives on the Administration Tradition-From Antiquity to the Twentieth Century; Papers from the History of Economics Society Conference, 1990. Edited by S. Todd Lowry. Brookfield, Vt.: Edward Elgar Publishing Company

46. Ghazanfar, S.M. and A. Azim Islahi. "Explorations in Medieval Arab-Islamic Economic Thought: Some Aspects of Ibn Qayyim's Economics (691-751AH/1292-1350AD)" History of Economic Ideas (Italy) 1997. 5:1:7-25

47. Ghazanfar, S.M. Medieval Islamic Economic Thought: Filling the 'Great Gap' in European Economics; Routledge-Curzon Publishers, London, 2003.

48. Ghazanfar, S.M. Islamic Civilization: History, Contributions, and Influence-A Compendium of Literature; Rowman-Littlefield Publishing Group, Scarecrow Press, Lanham, Maryland, 2006.

49. Ghazanfar, S.M. "Capitalistic Tradition in Early Islamic Civilization” Journal of Oriental 
and African Studies (Athens, Greece) 18, (2009): 139-157.

50. Gilson, Etienne. Reason and Revelation in the Middle Ages. New York: Charles Scribner's Sons, 1948.

51. Gimpel, Jean. The Medieval Machine: The Industrial Revolution of the Middle Ages. New York: Holt, Rinehart and Winston, 1976.

52. Goitein, S.D. "Between Hellenism and Renaissance: Islam, the Intermediate Civilization" Islamic Studies 2:2 (June, 1963):217-233.

53. Goldstein, Thomas. Dawn of Modern Science. Boston, Mass.: Houghton Mifflin Company, 1988.

54. Gomez, Eusebio. "Muslim Theology in its Bearing on Scholasticism." Clergy Review 6 (1933): 99-109.

55. Guillaume, Alfred. "Philosophy and Theology." In The Legacy of Islam. Edited by Sir Thomas Arnold and Alfred Guillaume. Oxford, England: The Clarendon Press, 1931.

56. Hammond, R. The Philosophy of Alfarabi and Its Influence on Medieval Thought, New York: Hobson Press, 1947.

57. Harris, C.R.S. Duns Scotus, 2 Volumes. New York: The Humanities Press, 1959.

58. Haskins, Charles H. The Renaissance of the Twelfth Century. Cambridge, Mass: Harvard University Press, 1927.

59. Haskins, Charles H. Studies in the History of Medieval Science. Cambridge, Mass.: Harvard University Press, 1924.

60. Haskins, Charles H. "Science at the Court of Emperor Frederick II." American History Review 27.4 (July, 1922): 669-694.

61. Haskins, Charles H. 1925. “Arab Science in the Western World.” ISIS, 17( 1925): 478-85.

62. Havighurst, Alfred F. (Editor). The Pirenne Thesis: Analysis, Criticism and Revision. Lexington, Mass.: D.C. Heath \& Company, 1969.

63. Hayes, John R (Editor). The Genesis of Arab Civilization: Source of Renaissance. Cambridge, Mass.: MIT Press, 1983.

64. Heaton, Herbert. Economic History of Europe, Revised Edition. New York: Harper \& Brothers, Publishers, 1948.

65. Hitti, Phillip K. The Arabs: A Short History. Princeton, N.J.: Princeton University Press, 1943.

66. Hitti, Phillip K. An Arab-Syrian Gentleman and Warrior in the Period of the Crusades: Memoirs of Usamah Ibn-Munqidh. Translated from Original. New York: Columbia University Press, 1929.

67. Hoyt, Edwin P. Arab Sciences: Discoveries and Contributions. New York: Thomas Nelson, Inc., Publishers, 1975. 
68. Huff, Toby E. The Rise of Early Modern Science: Islam, China, and the West. New York: Cambridge University Press, 1993.

69. Ito, Shuntaro. "The Twelfth Century Renaissance: Arabic Influences on the West" (Summary article, from the author's book of the same title). Tokyo, Japan. 1993.

70. Izzedin, Nejla. The Arab World: Past, Present, Future. Chicago, Illinois: Henry Regnery Company, 1953.

71. Johnson, E.N. “American Medievalists and Today.” Speculum, 28 (October, 1953):844854.

72. Al-Khalil, Jim. Pathfinders: The Golden Age of Arabic Science. London. Penguin Books Ltd, 2010.

73. Kramers, J.H. "Geography and Commerce" In The Legacy of Islam. Edited by Sir Thomas Arnold and Alfred Guillaume. Oxford, England: The Clarendon Press, 1931.

74. Krueger, Hilmer C. "Economic Aspects of Expansionary Europe." In Twelfth Century Europe and the Foundations of Modern Society. Edited by Marshall Claggett, Gaines Post and Robert Reynolds. Madison, Wisconsin: University of Madison Press, 1961.

75. Labib, Subhi Y. "Capitalism in Medieval Islam.” Journal of Economic History. 29 (1969):79-96

76. Landau, Rom. Arab Contribution to Civilization. San Francisco, California: American Academy of Asian Studies, 1958.

77. Lane, Rose Wilder. The Discovery of Freedom: Man's Struggle against Authority. New York: John Day Company, 1943.

78. Laroix, Paul. Science and Literature in the Middle Ages and the Renaissance. New York: Frederick Ungar Publishing Company, 1878 (reprinted 1964).

79. Leff, Gordon. Medieval Thought: St. Augustine to Ockham. Chicago, Illinois: Quadrangle Books, Inc. 1958.

80. Lewis, Archibald (Editor). The Islamic World and the West, 622-1492 AD. New York: John Wiley and Sons, 1970.

81. Lewis, Archibald. Nomads and Crusaders: A.D. 1000-1368. Bloomington, Indiana: Indiana University Press, 1988.

82. Lindberg, David C. The Beginnings of Western Science: The European Scientific Tradition in Philosophical, Religious, and Institutional Context, 600 B.C. to A.D. 1450. Chicago, Ill.: University of Chicago Press, 2007.

83. Lowry, S. Todd (Editor). Perspectives on the History of Economic Thought; Vol.VII: Perspectives in the Administrative Tradition: From Antiquity to the Twentieth Century. Brookfield, Vt.: Edward Elger Publishing Company, 1992.

84. Lyons, Jonathan Lyons. The House of Wisdom: How the Arabs Transformed Western Civilization. New York, New York. Bloomsbury Press, 2009. 
85. Maalouf, Amin. The Crusades through Arab Eyes (Translated by Jon Rothschild). New York: Schocken Books, 1985.

86. Makdisi, George. "The Scholastic Method in Medieval Education: An Inquiry into its Origins in Law and Theology." Speculum: A Journal of Medieval Studies 49 (1974):640661

87. Makdisi, George. "Interaction between Islam and the West." Revue des studes Islamique. 44 (1976):287-309.

88. McCabe, Joseph. The Splendor of Moorish Spain. London: Watts and Company, 1975.

89. Menocal, Maria Rosa. The Arabic Role in Medieval Literary History: A Forgotten Heritage. Philadelphia: University of Pennsylvania Press, 1987.

90. Morgan, Michael Hamilton. Lost History: The Enduring Legacy of Muslim Scientists, Thinkers, and Artists. Washington, D.C. National Geographic, 2007.

91. Murdoch, John E. and Edith D. Sylla (Editors). The Cultural Context of Medieval Learning (1973 Conference Proceedings). Boston, Mass.: D. Reidel Publishing Company, 1975.

92. Myers, Eugene A. Arabic Thought and the Western World. New York: Frederick Ungar Publishing Company, 1964.

93. Nakosteen, Mehdi. History of Islamic Origins of Western Education, A.D. 800-1350. Boulder, Col.: University of Colorado Press, 1964.

94. Nash, Gary B., Charlotte Crabtree, and Rose Duncan. History on Trial: Culture Wars and Teaching the Past. New York: Alfred A. Knopf Publishers, 1997.

95. O'Leary, De Lacy. Arabic Thought and Its Place in History. New York: Kegan Paul, Tench, Trubner \& Co., Ltd., 1922.

96. Packard, Sidney R. 12th Century Europe: An Interpretative Essay. Amherst, Mass.: University of Massachusetts Press, 1977.

97. Pribram, Karl. A History of Economic Reasoning. Baltimore, Maryland: The Johns Hopkins University Press, 1983.

98. Qadir, Abdul. Philosophy and Science in the Islamic World. London: Croom Helm., 1988.

99. Rashed, Roshdi. "Science as a Western Phenomenon." Fundamenta Scientiae. 1 (1980):721

100. Rescher, Nicholas. Studies in Arabic Philosophy. Pittsburgh, Penn.: University of Pittsburgh Press, 1966.

101. Ronan, Colin A. Science: Its History and Development among the World's Cultures. New York: Facts on File Publishers, Hemlyn Publishing Group Limited, 1982.

102. Russell, Josiah C. Twelfth Century Studies. New York: AMS Press, 1978.

103. Russell, Josiah C. "Hereford and Arabian Science in England about 1175-1200." ISIS. 18:1 (July, 1932) 14-25. 
104. Said, Edward. Orientalism. New York: Vintage Press, 1978.

105. Samuels, Warren J. "The History of Economic Thought as Intellectual History." History of Political Economy 6 (Fall, 1974): 305-323.

106. Sarton, George. Introduction to the History of Science; 5 Volumes. Baltimore, Maryland: Williams and Wilkins, 1927-48.

107. Sarton, George. A Guide to the History of Science. Waltham, Mass.; Chronica Botanica Company, 1952.

108. Sarton, George. The Incubation of Western Culture in the Middle East. Library of Congress Lecture (March 1950). Washington, D.C.: U.S. Government Printing Office, 1951.

109. Sauvaget, Jean (Editor). Introduction to the History of the Muslim East: A Bibliographic Guide. 2nd Edition (recast by Claude Cahen). Berkeley, Calif.: University of California Press, 1965.

110. Sharif, M.M. (Editor). A History of Muslim Philosophy, 2 Volumes. Weisbaden, Germany: Otto Harrassowitz, 1966.

111. Sheikh, M. Saeed. Islamic Philosophy. London: The Octagon Press, 1982.

112. Southern, R.W. The Making of the Middle Ages. New Haven, Conn.: Yale University Press, 1959.

113. Southern, R.W. Western Views of Islam in the Middle Ages. Cambridge, Mass.: Harvard University Press, 1963.

114. Spengler, Joseph J. "Economic Thought of Islam: Ibn Khaldun." Contemporary Studies in Society and History.6.3 (1964): 268-306

115. Spengler, Joseph J. "Notes on the International Transmission of Economic Ideas." History of Political Economy 2 (Spring, 1990): 133-151

116. Stiefel, Tina. The Intellectual Revolution in Twelfth Century. New York: St. Martin's Press, 1985.

117. Thomas, Bertram. The Arabs: The Life History of a People Who Have Left Their Deep Impression on the World. Garden City, N.Y.: Doubleday, Doran \& Co., Limited, 1937.

118. Thompson, Diane P. "Paradigm Lost: Western Civilization and the Orient Unexpressed." Northern Virginia Review, no.10 (Fall, 1995): 5-8.

119. Thompson, James W. "The Introduction of Arabian Science into Lorraine in the Tenth Century.” ISIS. 38:12 (May, 1929.) 184-193

120. Treagold, Warren (Editor). Renaissances before the Renaissance: Cultural Revival of Late Antiquity and the Middle Ages. Stanford, Calif.: Stanford University Press, 1984.

121. Wallace-Murphy, Tim. What Islam Did for Us: Understanding Islam's Contribution to Western Civilization. London. Watkins Publishing, 2006.

122. Walsh, James J. High Points of Medieval Culture. Freeport, N.Y.: Books for Libraries 
Press, 1937 (reprinted 1969).

123. Watt, W. Montgomery. Islamic Surveys: The Influence of Islam on Medieval Europe. Edinburgh, England: Edinburgh University Press, 1972.

124. Watt, W. Montgomery. What is Islam? 2nd Edition. New York: Longman, Green and Company, 1979.

125. Weaver, Henry G. The Mainspring of Human Progress. New York: The Foundation for Economic Education, Inc., 1953.

126. Welborn, Mary C. "Lotharingia as a Center of Arabic Scientific Influence in the Eleventh Century" ISIS. 16 (1931):188-99.

127. White, Hayden. "The Politics of Historical Interpretation: Discipline and DeSublimation" Critical Inquiry. 9 (1982):113-137. 